\title{
7 \\ Public Expenditure on Agriculture and its Impact
}

\author{
Samuel Benin
}

\subsection{Introduction}

Along with the creation of enabling policies, public investment in agriculture plays a crucial role in promoting agricultural growth and conditioning its distributional outcomes. These linkages are well established in the literature (Aschauer 1989; Barro 1990; Thirtle et al. 2003; Fan 2008), but their realization requires sufficient levels of public spending, the right types of spending (e.g., amongst agricultural research, extension, irrigation, input subsides, roads, education, and health), an appropriate distribution of spending across geographic areas to improve the distributional outcomes and impacts, and striking an appropriate balance between capital investment for long-term growth and recurrent costs incurred in providing public services.

This chapter examines past patterns of public spending on agriculture in Ghana, and asks whether Ghana has invested enough resources in agriculture and how the patterns of investment in the sector have impacted agricultural productivity growth.

The scope and rigor of the analysis is constrained by the available data, and only partial insights are possible drawing on a variety of data sources and studies. The chapter is structured as follows. The next section examines trends in public agriculture spending over the period 1961-2012, and disaggregates that spending into the cocoa and noncocoa sectors. The noncocoa subsector is managed by the general government sector within the national budget and procurement systems, whereas the cocoa subsector is managed exclusively by a public corporation or state-owned enterprise-Ghana Cocoa Board (Cocobod)-directly from the proceeds of the export of cocoa beans purchased from the farmers. Relative to the subsector's value-added, the amount spent by the Cocobod on the cocoa subsector far outweighs the amount spent by the government on the noncocoa subsector, which includes 
all the country's food staples. To obtain more detailed insights about the types of spending within the agricultural sector, we draw on a study by Benin et al. (2012) who provide some insights into the types of government spending and their regional allocation for the period 2000-7. The subsequent section then reports on two econometric analyses that estimate the impact of public spending on agricultural productivity growth, and provide some useful insights into the marginal returns to public investments in the cocoa and noncocoa subsectors, and by type of public investment. This is followed by a discussion of the government's recent attempts to promote noncocoa agricultural growth through several new subsidy programs, and this leads to our concluding section.

\subsection{Trends in Public Agriculture Spending, 1961-2012}

\subsubsection{Data Sources}

Data on public agriculture expenditure in Ghana were compiled from various national and international sources from 1961 to 2012 for the agriculture sector as a whole, and separately for the cocoa and noncocoa subsectors (Table 7.1). The noncocoa subsector includes noncocoa crops (including food staples), livestock, forestry, and fishery. Agricultural production data were compiled from FAOStat, and disaggregated for the cocoa and noncocoa subsectors.

Table 7.1. Data sources for public spending and agricultural output, 1961-2012

\begin{tabular}{|c|c|c|}
\hline Variable & Description/Disaggregation & Data sources \\
\hline $\begin{array}{l}\text { Total } \\
\text { expenditure } \\
(T E)\end{array}$ & $\begin{array}{l}\text { Total government expenditure in } \\
\text { constant } 2006 \text { GHS, million }\end{array}$ & \multirow{2}{*}{$\begin{array}{l}\text { Stryker (1990), IMF }(1998,2000 \text {, } \\
\text { 2005), Kolavalli et al. (2012), } \\
\text { MoFA (2013), GCB (2013), CAGD } \\
\text { (2011, 2013, 2014), IFPRI (2015), } \\
\text { World Bank (2015) }\end{array}$} \\
\hline $\begin{array}{l}\text { Agricultural } \\
\text { public } \\
\text { expenditure } \\
(\text { agEXP) }\end{array}$ & $\begin{array}{l}\text { Government expenditure on } \\
\text { agriculture in constant } 2006 \text { GHS, } \\
\text { million, disaggregated into: } \\
\text { - Cocoa subsector } \\
\text { - Noncocoa subsector (noncocoa } \\
\text { crops, livestock, forestry, fishery) }\end{array}$ & \\
\hline $\begin{array}{l}\text { Agricultural } \\
\text { output }(Y)\end{array}$ & $\begin{array}{l}\text { Gross output in constant 2004-6 } \\
\text { GHS, million, divided by } \\
\text { agricultural area (including arable } \\
\text { land, permanent crops, permanent } \\
\text { meadows and pastures, forest area, } \\
\text { and inland water), disaggregated into: } \\
\text { - Cocoa subsector } \\
\text { - Noncocoa subsector }\end{array}$ & FAO (2016) \\
\hline
\end{tabular}


Appendix Table 7A shows details of how the annual expenditure data were compiled, including the sources for each data point.

\subsubsection{Trends in Public Agriculture Expenditure and Output per Hectare}

Trends in agricultural public expenditure and gross agricultural output per hectare of agricultural land are shown in Figures 7.1 and 7.2, respectively, and Table 7.2. The ratio of expenditure to output is shown in Figure 7.3 There have been considerable fluctuations in public spending over the years, driven by changing governments and their policy agendas, but very little upward trend until the 1990s after the economic reforms. Spending by the Cocobod on the

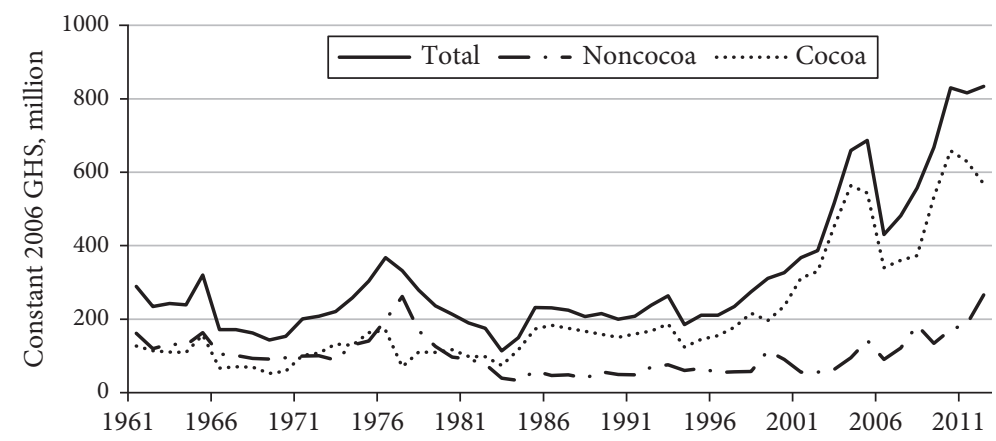

Figure 7.1. Agricultural public expenditure in Ghana by subsector, 1961-2012 Note: GHS = Ghanaian cedi. Expenditure on the noncocoa subsector is by the government and that on the cocoa subsector is by the Cocobod. Total is from adding the two.

Source: Author's illustration based on compiled data (see Tables 7.1 and 7A).

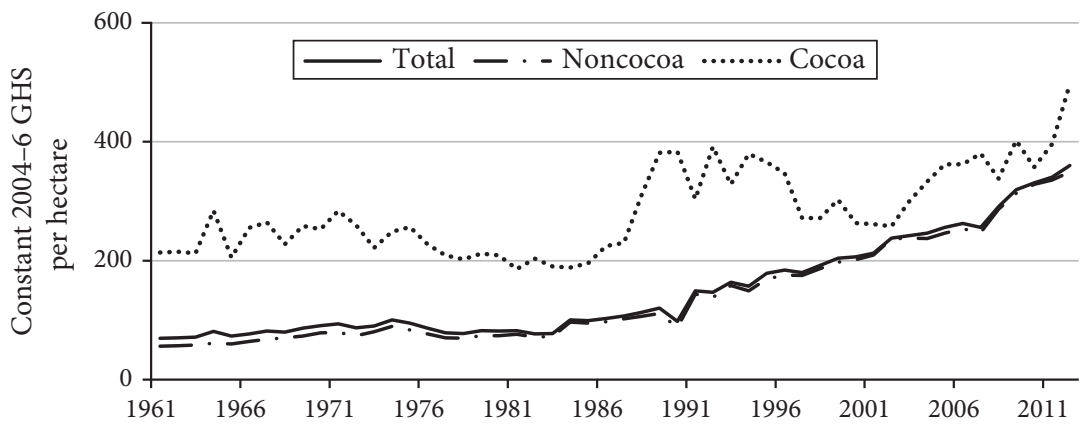

Figure 7.2. Agricultural output per hectare by subsector in Ghana, 1961-2012 Note: GHS = Ghanaian cedi.

Source: Author's illustration based on FAO (2016). 


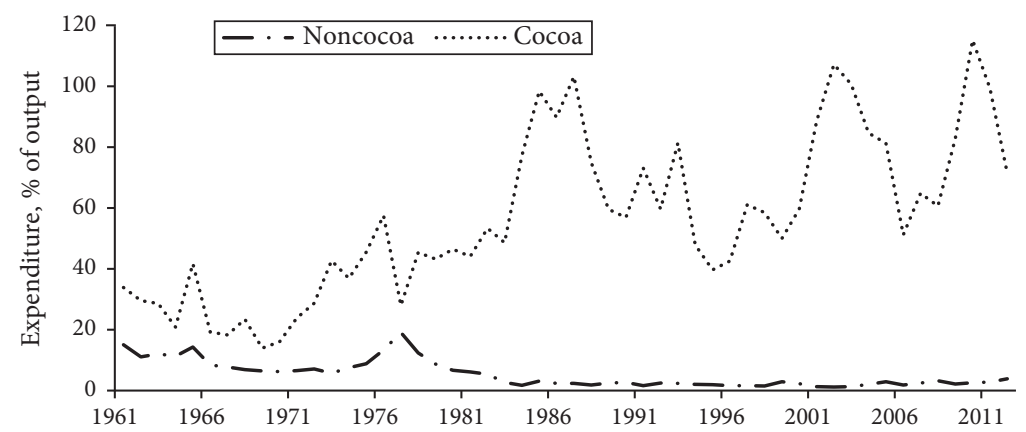

Figure 7.3. Ratio of agricultural public expenditure to output by subsector in Ghana, 1961-2012

Note: Expenditure on the noncocoa subsector is by the government and that on the cocoa subsector is by the Cocobod.

Source: Author's illustration based on compiled data (see Tables 7.1 and 7A).

Table 7.2. Agricultural expenditure and output per hectare by subsector in Ghana, 1961-2012

Indicator $\quad 1961-5 \quad 1966-71 \quad 1972-9 \quad 1980-1 \quad 1982-92 \quad 1993-2000 \quad 2001-8 \quad 2009-12$

Agriculture expenditure, growth rate (\%)

$\begin{array}{lrrrrrrrr}\text { Total } & 2.3 & 1.0 & 3.6 & -11.3 & 4.2 & 6.1 & 4.3 & 6.7 \\ \text { Cocoa } & 3.8 & 3.9 & -3.0 & -15.6 & 5.9 & 6.4 & 1.0 & 1.5 \\ \text { Noncocoa } & 1.0 & -1.4 & 9.0 & -6.1 & 1.1 & 4.9 & 17.8 & 23.7\end{array}$

Agriculture expenditure (\% of output)

Total $\quad 17.4 \quad 9.5 \quad 15.3$

$\begin{array}{llll}\text { Cocoa } & 30.1 & 19.1 & 40.7\end{array}$

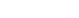

Noncocoa

12.7

$7.0 \quad 10.1$

6.4

2.5

2.0

$76.5 \quad 90.3$

Agriculture output per hectare, growth rate (\%)

\begin{tabular}{lrrrrrrrr} 
Total & 2.4 & 4.2 & -2.4 & 0.8 & 5.9 & 3.8 & 3.5 & 3.9 \\
Cocoa & 3.1 & 3.4 & -6.0 & -11.1 & 5.8 & 6.9 & 10.0 & 7.7 \\
Noncocoa & 2.1 & 4.5 & -1.8 & 2.8 & 5.8 & 4.1 & 3.2 & 3.6 \\
\hline
\end{tabular}

Note: Expenditure on the noncocoa subsector is by the government and that on the cocoa subsector is by the Cocobod. Total is from adding the two.

Source: Author's calculation based on compiled data (see Tables 7.1 and 7A).

cocoa subsector has far exceeded government spending on the noncocoa subsector, both in terms of the absolute amount spent and as a share of the value of output. This gap widened in the 1990s and has only recently begun to close with an acceleration in the growth rate of government spending on the noncocoa subsector. Average land productivity has grown slowly but steadily over the years, but despite the spending bias towards the cocoa subsector, the long-term trend has been for land productivity to grow at similar rates in the two subsectors. 
To better understand these trends and fluctuations in public expenditure, it is useful to relate them to the underlying agricultural policies of successive governments. Major influential factors include the following:

- Until 1990, there was direct agricultural production by the government through state farms and cooperatives.

- Subsidization of farm production stopped in 1990 and returned in 2007.

- Implementation of policies and strategies was mostly through projects until the 1990s and then through programs and sector-wide approaches afterward.

- Government and public spending was decentralized, including the enactment of the Local Government Law in 1988, establishment of the District Assembly Common Fund in 1993, and implementation of direct district budgeting and execution starting in 2012.

- Agricultural public expenditure reviews were conducted in 1977, 1998, 2006, and 2012.

- The country signed the CAADP compact in 2009.

- Specific to the cocoa subsector, Cocobod is constitutionalized in 1984, licensed buying companies are introduced in 1993, the Produce Buying Company is privatized in 1999 , and a hi-tech program is initiated in 2004.

Table 7.2 summarizes the trends in public expenditure and land productivity by sub-periods that correspond to successive governments, beginning in 1961. A short summary of the agricultural policies of each period follows.

\subsubsection{1958 to 1966}

The post-Independence policies of the Convention People's Party government led by Dr. Kwame Nkrumah extended until 1966, and were dictated by the overall economic development agenda of rapid industrialization, which was primarily financed by taxing agriculture. An Agricultural Development Corporation (ADC) was established to promote the production of export crops (mainly cocoa) for foreign exchange earnings and production of industrial crops (mainly rubber, sugar cane, oil palm, and cotton) to feed the ambitious local factories that were being set up. As such, the bulk of agriculture expenditure was allocated to ADC and spent on input subsidies (imports of fertilizers, other chemicals, tractors, and implements) and on distribution and marketing of produce associated with the state farms. Following the ADC's forced closure 
in 1962, due to its accumulated large debts and unsuccessful large-scale production and marketing activities, state farms and cooperatives were established to take over ADC's projects and the ministry's stations. Price controls, input and credit subsidies, and obligatory credit allocations continued to be used to support the heavy state involvement in agricultural production, distribution, and marketing (Stryker 1990; Dappah 1995). At the time of Nkrumah government's overthrow in 1966, there were 105 state farms (42 of them were inherited from ADC) cultivating about 22,396 hectares, with 62 percent under permanent crops (mainly rubber, oil palm, sugar cane, cotton, coconut, banana, and kola nut) and the remaining 38 percent under food crops (mainly maize and rice) (Austin and Luckham 1975). As Table 7.2 shows, agriculture expenditure in 1961-5 grew at an annual average rate of 2.3 percent, with expenditures on cocoa growing faster (3.8 percent) than combined expenditures on the noncocoa subsector (1.0 percent). The amount spent as a share of the respective subsector's agricultural output was much higher for cocoa (30.1 percent) than for noncocoa (12.7 percent). Growth in the land productivity for the agricultural sector as a whole averaged 2.4 percent year, with growth in the noncocoa subsector ( 2.1 percent) being lower compared with the growth in the cocoa subsector (3.1 percent).

\subsubsection{1966 to 1971}

This era was governed by the National Liberation Council military government under Lieutenant General Joseph Arthur Ankrah and Lieutenant General Akwasi Afrifa (1966-9), followed by the second republic under Doctor Kofi Busia and the Progress Party (1969-72). The main strategy of the National Liberation Council government that had significant bearing on the level of agriculture expenditure and how it was allocated was in trying to ward off the domestic crisis (mainly, high food prices and low producer prices) and to pay off the large debts amassed by the previous government (Austin and Luckham 1975). Doing so involved stimulating more agricultural primary exports (cocoa and timber) and cutting back on direct state involvement in agricultural production. For example, between the 1966 coup d'état and May 1968, the producer price of cocoa was doubled, no new state farms were established, and some state farms and factories were closed or sold off. This trend continued into the Busia-led government. Although there was marked structural change in the rest of the economy (especially nationalism and promotion or takeover of businesses by Ghanaians), agricultural policy and finance mostly continued as before-that is, promoting production of cocoa for export, promoting industrial crops to feed factories, importing and 
subsidizing fertilizer and capital for production of these crops, and importing food to feed the urban consumers.

The biased support to state farms and individual large-scale farms or farmers is reflected in the lending practices to the sector by banks that were obligated to provide agricultural loans. The banks typically gave loans to those farms operating 20-1,000 acres of farmland and producing industrial crops or engaged in agro-industry (Austin and Luckham 1975). As Table 7.2 shows, agriculture expenditure during this era grew at an average rate of 1.0 percent per year, with expenditures on cocoa growing much faster (3.9 percent) than combined expenditures on the noncocoa subsector ( -1.4 percent). Here too, the amount spent as a share of the respective subsector's agricultural output was more than twice as high for cocoa (19.1 percent) as it was for noncocoa (7.0 percent). Growth in land productivity for the agricultural sector as a whole averaged 4.2 percent per year, which was dominated by growth in the noncocoa subsector (4.5 percent), as compared with growth in the cocoa subsector (3.4 percent).

\subsubsection{1972 to 1979}

Promotion of private large-scale agricultural production was enhanced following the second coup d'état and rule of the country by the National Redemption Council military government under General Ignatius Acheampong (1972-5) and the Supreme Military Council government under Lieutenant General Frederick Akuffo (1975-9). It was during this era that the first agricultural-specific initiatives were launched-Operation Feed Yourself, which aimed to help reduce food imports, and Operation Feed Your Industries, which aimed to continue providing raw materials to feed local factories. During these years, fertilizer subsidies were substantial, and bank loans to large-scale operators increased rapidly (Quartey-Papafio 1977). Although small-scale farmers were not directly supported under these policies and interventions, they seem to have had easy access to fertilizer and seed, which contributed favorably to their well-being (Wiemers 2015). In general, the economic development agenda of rapid import-substitution industrialization continued.

As Table 7.2 shows, agriculture expenditure in $1972-9$ grew at an average rate of 3.6 percent year, with expenditures on cocoa experiencing a declining growth rate ( -3.0 percent) and combined expenditures on the noncocoa subsector rising rapidly ( 9.0 percent). Still, the amount spent as a share of the respective subsector's agricultural output was much higher for cocoa (40.7 percent) than for noncocoa (10.1 percent). There was a declining trend 
in land productivity for the entire agricultural sector, which averaged -2.4 percent per year, with the decline in the noncocoa subsector ( -1.8 percent) being lower than in the cocoa subsector (-6.0 percent).

\subsubsection{1979 to 1981}

Following another coup d'état in June 1979 came the brief military government of the Armed Forces Revolutionary Council, led by Flight Lieutenant Jerry John Rawlings from June to September 1979, and then the third republic, led by the government of the People's National Party under Doctor Hilla Limann from September 1979 to December 1981. Dr. Limann's government launched a two-year program, Action Programme for Agricultural Production, 1980-1 (Andah 1980). As Table 7.2 shows, there was negative growth in most indicators during this relatively short period, likely reflecting the widely acclaimed economic mismanagement of the government prior to the coup d'état. The amount spent as a share of the respective subsector's agricultural output continued to be much higher for cocoa ( 45.3 percent) than for noncocoa (6.4 percent).

\subsubsection{1982 to 2000}

Jerry Rawlings came back to power, first through another coup d'état under the government of the Provisional National Defence Council from the eve of 1982 until 1993, and then through the ballot box, ushering in the fourth republic under the National Democratic Congress government until January 2001. This roughly twenty-year period is known for the Structural Adjustment Program, which is locally called the Economic Recovery Program. In addition, numerous agricultural sector-specific plans, strategies, projects, or programs were launched. As expected with the structural adjustment, there was a substantial cutback in government spending in general, and agricultural input subsidies were stopped in 1990. Overall agriculture expenditure grew at an average rate of 4.2 percent in 1982-92 and 6.1 percent in 1993-2000, with expenditures on the cocoa subsector growing faster than combined expenditures on the noncocoa subsector. As Table 7.2 shows, the amount spent as the share of the respective subsector's agricultural output continued to be much higher for the cocoa subsector than for the noncocoa subsector.

With the launch of the Local Government Law, the decentralization policy, and institution of the District Assembly Common Fund, direct spending and accounting of expenditures at lower levels increased, likely increasing the targeting of expenditures for agricultural and rural development (Mogues and Benin 2012). Comparative growth in land productivity was mixed, 
however; whereas it was equal (5.8 percent per year) in the cocoa and noncocoa subsectors in 1982-92, it was higher for the cocoa subsector (6.9 percent per year) than for the noncocoa subsector (4.1 percent percent) in 1993-2000.

\subsubsection{2001 to 2008}

With the National Patriotic Party, led by John Agyekum Kufuor, coming into power in January 2001, there was a shift from project-based agricultural development to program-based and sector-wide approaches. Some of the most influential approaches on the sector were the Presidential Special Initiatives, the Agricultural Services Subsector Investment Program, and the Food and Agricultural Sector Development Policy, among others. It was during this era that CAADP, the Africa-wide, agriculture-led development initiative, was launched in the continent, though Ghana did not officially complete and sign its national compact until 2009. The CAADP raised the profile of agricultural expenditures and influenced the definition and accounting of agriculture expenditure (the debate of which continues today).

In 2007, the government announced that it would reintroduce agricultural input subsidies (fertilizer, block farms, mechanization, and buffer stock) and then went on to spend an average of GHS 7.9 million each year in 2007 and 2008 to implement it (Benin et al. 2013). Direct spending at subnational levels continued. As Table 7.2 shows, at the national level, agriculture expenditure during this era grew at an average rate of 4.3 percent per year, with growth in expenditure on the cocoa subsector being almost stagnant (1.0 percent) compared with growth in expenditure on the noncocoa subsector (17.8 percent). The amount spent as a share of the respective subsector's agricultural output continued to be much higher for cocoa than for noncocoa. For example, the share of expenditure on cocoa as a share of the subsector's agricultural output was 76.5 percent, compared with only 2.1 percent for the noncocoa subsector. Growth in land productivity for the entire agricultural sector averaged 3.5 percent per year, with the average growth being lower in the noncocoa subsector (3.2 percent), compared with growth in the cocoa subsector (10.0 percent).

\subsubsection{2009 to 2012}

From January 2009 until 2016, the National Democratic Congress has been the ruling government in Ghana-first under Professor John Evans Atta Mills (2009-12) and then John Dramani Mahama (2012-16). Some of the key policies, programs, and projects undertaken during this era include the Ghana Commercial Agriculture Project and the Soil, Land, and Water 
Management Project. Direct spending at subnational levels continued. In 2012, the composite budgeting system was introduced for all metropolitan, municipal, and district assemblies ${ }^{1}$ to effect fiscal decentralization of the 1988 Local Government Law, in which all decentralized functions of government are directly managed by the assemblies at the respective levels of government.

Agricultural input subsidies also remained strong. The overall trends in agriculture expenditure at the national level are similar to trends seen in the preceding periods analyzed. For example, agriculture expenditure during 2009-12 grew at an average rate of 6.7 percent per year, with expenditure on cocoa barely growing (1.5 percent), as compared with combined expenditure on the noncocoa subsector (23.7 percent). The share of expenditure on cocoa as a share of the subsector's agricultural output was 90.3 percent per year, compared with only 2.9 percent per year for the noncocoa subsector. Growth in land productivity for the entire agricultural sector was 3.9 percent, with growth in the cocoa subsector (7.7 percent) outperforming growth in the noncocoa subsector (3.6 percent).

\subsubsection{Overall trends from 1961 to 2012}

To summarize, overall agricultural policy and expenditure have favored the cocoa subsector. Between 1961 and 2012, the periods over which the data used here are available, agricultural expenditure on the cocoa subsector grew at an average rate of 3.7 percent per year, compared with -0.3 percent for the noncocoa subsector. The share of expenditures on the cocoa subsector as a share of the subsector's agricultural output was 57.6 percent per year, compared to only 3.7 percent per year for the noncocoa subsector. The annual average growth rate in land productivity for the entire agricultural sector averaged 3.3 percent per year, driven by growth in the noncocoa subsector (3.7 percent), as compared with growth in the cocoa subsector (1.0 percent).

In terms of fulfilling its Maputo Declaration target of allocating at least 10 percent of total government spending to agriculture, Ghana has failed to meet this requirement, amidst several reports that show otherwise following confusion on differentiating mostly expenditures of the government sector and those of public corporations such as the Ghana Cocoa Board (Benin 2014). Considering only expenditures of the general government sector (i.e., expenditures on the noncocoa subsector as shown in Table 7.2), the

\footnotetext{
${ }^{1}$ These include six metropolitan assemblies, forty-nine municipal assemblies, and 161 district assemblies.
} 
share of government expenditure on agriculture as a share of total government expenditure amounts to only 2.1 percent during 2001-8 and 2.8 percent during 2009-12. This is low even by African standards (Benin and Yu 2013), especially as it includes all the country's food staples. When expenditures of the Ghana Cocoa Board are included as part of public expenditures on agriculture, and expenditures of other public corporations are included as part of total public expenditure, Benin (2014) estimates the share to be about 3.8-5.3 percent, which still falls short of the 10 percent Maputo Declaration target.

\subsubsection{Composition of Public Spending on Agriculture, 2000-7}

Benin et al. (2012) provide more detailed insights into the composition of public spending in rural areas for 2000-7. Their analysis includes levels and trends for public spending differentiated by type of spending and by regional priorities. Government spending on agriculture is channeled through a number of ministries and institutions ${ }^{2}$ and Benin et al. (2012) report these by major channel in Table 7.3. The government's resource allocation to the agricultural sector increased by nearly four times between 2000 and $2007^{3}$. Interestingly, MoFA, the conventional ministry responsible for the agricultural sector, accounted for only 25 percent of total public spending on the sector, down from about one half of the total expenditures in the sector in the mid-1990s (MoFA 1999). The share for CSIR average 14.2 percent, increasing from 12.5 percent in 2000 to 27.2 percent in 2007. This shows that agencies other

${ }^{2}$ Public spending on the agricultural sector takes place not only through conventional allocation by the Ministry of Agriculture, but also through various other government ministries, departments, and agencies, in addition to public corporations or state-owned enterprises. In Ghana for example, fishery and forestry each fall under their own separate ministry, both distinct from the Ministry of Food and Agriculture (MoFA), which is responsible for crops, other than cocoa, and livestock. Cocoa is managed by the Ghana Cocoa Board (Cocobod), which in turn is under the Ministry of Finance and Economic Planning. Agricultural R\&D is managed by the Council for Scientific and Industrial Research (CSIR), which reports to the Ministry of Education, Sports, and Science. Other expenditures related to agriculture in Ghana are undertaken by the Ministry of Trade and Industry (such as spending relating to food imports and agricultural marketing and trade), the Ministry of Roads and Transport (such as feeder roads development), the Ministry of Local Government and Rural Development, Ministry of Women and Children's Affairs, Ministry of Manpower Development and Employment (all three allocate resources to agricultural community-based development projects), and the Presidential Special Initiatives on agriculture. Thus, even with a clearly defined agricultural sector, it is usually difficult to obtain expenditure data on the sector when the audited public accounts do not have clearly defined line items for each of the above, and as the ministries and institutions evolve.

${ }^{3}$ Unless otherwise stated, all monetary values are in 2000 constant prices. 
Table 7.3. Government expenditures on agriculture and rural development (2000 GHS, millions)

\begin{tabular}{lcccccc}
\hline Year & MoFA and MoF $^{\mathrm{a}}$ & DoF $^{\mathrm{b}}$ & CSIR $^{\mathrm{c}}$ & Cocobod $^{\mathrm{d}}$ & PSI $^{\mathrm{e}}$ & Total \\
\hline 2000 & 5.16 & 0.94 & 3.80 & 20.51 & 0.00 & 30.41 \\
2001 & 4.74 & 0.73 & 3.63 & 22.71 & 0.00 & 31.81 \\
2002 & 5.30 & 0.68 & 4.50 & 18.06 & 0.00 & 28.54 \\
2003 & 11.13 & 0.72 & 3.88 & 25.10 & 1.48 & 42.31 \\
2004 & 19.96 & 3.93 & 6.36 & 36.84 & 2.92 & 70.01 \\
2005 & 14.56 & 2.08 & 5.08 & 36.43 & 5.47 & 63.62 \\
2006 & 28.47 & 5.57 & 24.17 & 53.49 & 5.65 & 117.35 \\
2007 & 27.60 & 8.65 & 31.44 & 37.69 & 10.30 & 115.68 \\
\hline
\end{tabular}

Notes: Government expenditures are financed from internally generated funds and from overseas developmental assistance in the form of loans and grants. GHS = Ghanaian cedi. In 2000, US\$ $1 \approx$ GHS0.55.

${ }^{\text {a }}$ Until 2005, MoF (Ministry of Fisheries) was part of MoFA (Ministry of Food and Agriculture).

${ }^{b}$ DoF is the Department of Forestry under the Ministry of Lands and Forestry.

${ }^{c}$ CSIR is the Council for Scientific and Industrial Research.

${ }^{d}$ Cocobod is the Ghana Cocoa Board.

e PSI is presidential special initiatives.

Source: Benin et al. (2012).

than the core ministry have gained over time in their relative importance for developing the sector.

\subsubsection{Spending issues}

Benin et al. (2012) identify some important issues about public spending. First, most of the government's expenditure on the sector is allocated to recurrent activities, particularly salaries (Figure 7.4), while donors are picking up most of the capital investments through various multilateral and bilateral grants and loans. This level of dependence on donor funding for development activities is also underestimated, because the data shown here do not include funds that some donors, including USAID, channel directly to partners in the private and NGO sectors. This high dependence on donor funding for capital investment in the sector raises questions about the government's capacity to sustain such crucial investments should donor priorities change.

Another issue identified by Benin et al. (2012) is that the lion's share of regional agricultural spending in the noncocoa subsector is allocated to the central and southern parts of the country, while the northern areas receive the least expenditure. In particular, the Volta region attracted the largest share of MoFA spending, followed by the Eastern, Ashanti, and BrongAhafo regions, while the Upper-West and Upper-East regions attracted the least. The amount spent per person is higher in the northern than the 


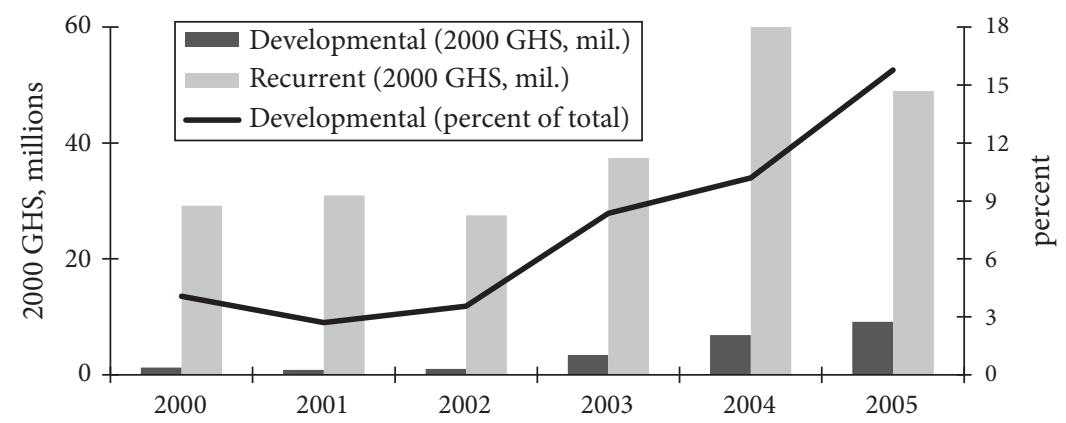

Figure 7.4. Government recurrent and developmental expenditures in agriculture (2000 GHS, millions)

Notes: GHS $=$ Ghanaian cedi.

Source: Benin et al.

Table 7.4. Government expenditures, by sector

\begin{tabular}{lcccccccr}
\hline & $\mathbf{2 0 0 0}$ & $\mathbf{2 0 0 1}$ & $\mathbf{2 0 0 2}$ & $\mathbf{2 0 0 3}$ & $\mathbf{2 0 0 4}$ & $\mathbf{2 0 0 5}$ & $\mathbf{2 0 0 6}$ & $\mathbf{2 0 0 7}$ \\
\hline Total (2006 GHS, billion) & 3.81 & 4.51 & 3.91 & 4.47 & 5.41 & 5.55 & 4.06 & 4.87 \\
Sector shares (\% of total expenditures) & & & & & & & \\
Agriculture & 2.4 & 1.2 & 1.4 & 1.4 & 1.8 & 2.6 & 2.2 & 2.5 \\
Education & 14.8 & 14.2 & 18.1 & 16.2 & 15.2 & 17.1 & 17.7 & 17.0 \\
Health & 3.0 & 3.8 & 5.2 & 5.1 & 4.6 & 5.7 & 6.7 & 6.8 \\
Transport \& communication & 2.3 & 1.3 & 0.7 & 1.1 & 1.1 & 1.3 & 1.3 & 1.4 \\
Defense & 2.2 & 2.4 & 2.3 & 2.5 & 1.9 & 2.3 & 2.3 & 2.1 \\
Other & 75.4 & 77.1 & 72.2 & 73.7 & 75.3 & 71.0 & 69.8 & 70.1 \\
\hline
\end{tabular}

Notes: GHS = Ghanaian cedi.

Source: Authors' calculation based on IFPRI (2015) and World Bank (2015).

southern areas, but the amount spent per hectare of land area is smaller in the north.

A final issue concerns the allocation of public expenditure across different types of spending. Access to other public goods and services such as education, health, roads, and other infrastructure can be as important as agricultural investment for promoting long-term agricultural productivity growth (Fan 2008). As shown in Table 7.4, the government has not neglected such nonagricultural spending, and total spending increased at an average rate of 2.5 percent per year between 2000 and 2007 in constant prices. However, the lion's share of the increase went to spending on education and health, while the spending shares for agriculture and transport (including all types of roads, ports, harbors and railways, etc.) and communication remained 
flat. This pattern of spending has been broadly consistent since the $1980 \mathrm{~s}$ (see Chapter 3). A relevant question is whether these were the best spending priorities for supporting agricultural productivity growth.

\subsection{Growth Effects of Public Spending on Agriculture}

Three key questions arise from our analysis of past patterns of public spending on agriculture. First, though a relatively small share of total government spending has been allocated to agriculture since 1961 (between 1 and 3 percent on average per year), has this been money well spent? Second, given the relatively high expenditure-to-output ratio in the cocoa subsector compared to the noncocoa subsector, has the noncocoa sector been unduly neglected? Third, we would like to know how effective the government's spending allocation across different types of investments and regions has been for agricultural growth. Our analysis draws on two recent studies. One study is by Benin (2016) who uses national-level data to estimate the marginal return to total public spending in agriculture over 1970-2012, and also the marginal returns for spending within the cocoa and noncocoa subsectors. We update this study using a revised model and data over 1961-2012. The other study by Benin et al. (2012) uses GLSS household survey data from 2005/6 and districtand region-disaggregated expenditure data over 2001-6 to estimate the productivity impacts of different types of public spending.

\subsubsection{Conceptual Framework}

The analysis in this chapter is based on a conceptual framework that sees public spending as contributing to a stock of public capital in rural areas, and this stock contributes to agricultural growth. This growth linkage can arise through various channels:

- Technology-advancing productivity effects, which typically derive from the yield-enhancing technologies of public expenditure in agricultural $\mathrm{R} \& \mathrm{D}$

- Human-capital-enhancing productivity effects, which typically derive from public expenditure in agricultural education, extension, and information, which all help raise the knowledge and skills of farmers and those engaged in agricultural production (Schultz 1982) 
- Transaction cost-reducing productivity effects, which derive from public expenditure on infrastructure (such as storage facilities, market information, and feeder roads) in the agricultural sector, which in turn contributes to improved access to input and output markets and thus reduces the cost of agricultural inputs and technologies (Sadoulet and de Janvry 1995)

- Crowding-in productivity effects, which is a second-order effect in which the increase in public capital induces an increase in private investment in agricultural production and along agricultural value chains.

In addition to the various channels through which productivity effects of public agriculture expenditure may materialize, the literature also shows that the effects are not the same for all types of expenditure. Also, the effects often materialize with a lag rather than contemporaneously. See Benin (2016) for further discussion.

These various effects can be captured in a model in which agricultural output is specified as a function of the stocks of both public and private capital in agriculture, as well as the use of resources like land, labor, and modern inputs, and other exogenous factors like rainfall. The stocks of public and private capital depend, respectively, on accumulated public and private spending over time, with relevant time-lag structures and depreciation rates. The stocks of public capital can also be disaggregated by type of spending. A second set of equations specifies that the stock of private capital and the use of other resources (land, labor, and modern inputs) is a function of the stock of public capital, along with other variables such as prices, policies, terms of trade, infrastructure, access to financial and technical services, access to input and output markets, land pressure, etc.

The literature on public investment analysis shows that the public spending decision, too, may be endogenous, since the amount spent or invested on a sector or activity may depend on the performance of the sector or returns to investment in the activity. So is the notion that growth in public capital is an endogenous process, that is, an outcome of growth in income rather than only a cause of it. As such, it is good practice to add a third equation to explain the level of public spending each year, typically using variables on political processes and institutional arrangements. When estimating the model, allowance must also be made for other variables that could be endogenous to the model or which are serially correlated over time. This modeling approach is well established in the literature (e.g.,, Aschauer 1989; Barro 1990, Thirtle et al. 2003, Fan 2008). 


\subsubsection{Disaggregated Impact of Public Spending in the Cocoa and Noncocoa Subsectors}

\subsubsection{The model}

Using national data for the period 1961-2012, we estimate a variant of Benin's (2016) model for Ghana's agricultural sector as a whole, and then separately for the cocoa and noncocoa subsectors. The model is a semi-reduced-form, single equation that is specified as follows:

$$
Y_{s t}=f\left(a g E X P_{s t}, a g S T K_{s t}, Z 1_{s t}, Z 2_{t}, t\right),
$$

where $Y$ is the value of gross agricultural output; agEXP is public agriculture expenditure; agSTK is public agriculture capital stock; $t$ is a time trend; and $Z 1$ and $Z 2$ are vectors of exogenous factors affecting agricultural output and use of inputs such as public nonagriculture expenditure, policies, institutions, infrastructure, prices, differentiating those that are subsector specific $(Z 1$, as related to some policies and institutions for example) and those that are not ( $Z 2$, such as land pressure, climate and agroecology).

Public agriculture expenditure equation is specified as follows:

$$
\operatorname{agEXP} P_{s t}=h\left(\operatorname{agSTK} K_{s t}, Z 3_{s t}, Z 4_{t}, t\right),
$$

where $\mathrm{Z} 3$ and $Z 4$ represents the variables that affect agEXP, some of which may also affect $Y$ and inputs and, therefore, are common to $Z 1$ and $Z 2$. Here too, differentiating those that are subsector specific $(Z 3)$ and those that are not $(Z 4)$. All the variables used in the estimation are observed with the exception of the public agriculture capital stock, agSTK, which was constructed using the following capital formation approach:

$$
\begin{gathered}
a g S T K_{s t}=I_{s t}+(1-\delta) a g S T K_{s t-1}, \\
a g S T K_{s, 1961}=\frac{I_{s, 1961}}{(\delta+r)}
\end{gathered}
$$

Where $I$ is the gross capital formation, $\delta$ is the depreciation rate, $r$ is the real interest rate, and the initial capital stock, agSTK ${ }_{1961}$, is estimated using the procedure of Kohli (1982). The annual values of $I$ are based on the share of capital expenditure in total expenditure for the entire economy (compiled from the same sources of expenditure listed in Table 7.1), $\delta$ is compiled from (Knoema 2016), and $r$ from the World Bank (2016). 
From the estimation, the elasticity of agricultural output with respect to public agriculture expenditure $\left(\vartheta_{s}\right)$ can be obtained as:

$$
\vartheta_{s}=\frac{\partial Y_{s}}{\partial a g E X P_{s}}+\frac{\partial Y_{s}}{\partial a g S T K_{s}}
$$

where $\partial$ refers to the partial derivative. The elasticity is interpreted as the percentage change in agricultural output $(Y)$ due to a 1 percent change in public agriculture expenditure (agEXP).

\subsubsection{Empirical model}

The empirical model estimated comprises two sets of a system of equations that can be written as:

$$
\begin{gathered}
a g E X P_{s t}=a+\gamma_{s} a g S T K_{s t}+Z 3_{s t}^{\prime} \tau_{s}+Z 4_{t}^{\prime} \pi+t+e_{t} \\
Y_{t}=a+\sum_{s} \beta_{s} a g E X P_{s t}+\sum_{s} \gamma_{s} a g S T K_{s t}+Z 1_{s t}^{\prime} \tau_{s}+Z 2_{t}^{\prime} \pi+t+e_{t}
\end{gathered}
$$

and

$$
\begin{gathered}
a g E X P_{s t}=a+\gamma_{s} a g S T K_{s t}+Z 3_{s t}^{\prime} \tau_{s}+Z 4_{t}^{\prime} \pi+t+e_{t} \\
Y_{s t}=a_{s}+\beta_{s} a g E X P_{s t}+\gamma_{s} a g S T K_{s t}+Z 1_{s t}^{\prime} \tau_{s}+Z 2_{t}^{\prime} \pi_{s}+t+e_{s t} .
\end{gathered}
$$

where (5a) and (5b) are for estimating the effect of subsector-disaggregated expenditures on total agricultural output, and (6a) and (6b) are separate equations for estimating the effect of subsector-disaggregated expenditures on subsector-disaggregated output.

Table 7.5 presents descriptive statistics of the specific variables used in the econometric analysis from 1961 to 2012. Most variables are self-explanatory but a few explanations are in order. For variables captured by $Z 3$ and $Z 4$, that is, factors affecting expenditures, we follow the literature closely and use, for example, GDP per capita (GDPCAP) to test Wagner's law that public expenditure rises constantly as income growth expands (Wagner 1883); and different shocks such as change in government and political party systems (GOVTYP), change in the minister of finance (MINFIN), change in the minister of agriculture (MINAG), change in the chief executive officer of the Cocobod (CEOCOB), policy reforms in the agriculture sector (AGPOL) and cocoa subsector (COPOL), and monetary policy (MONPOL) to test the displacement hypothesis (Peacock and Wiseman 1961). Another noncocoa-specific 
Table 7.5. Description and summary statistics of variables, 1961-2012 annual average

\begin{tabular}{|c|c|c|c|}
\hline Variable & $\begin{array}{l}\text { Name in } \\
\text { model }\end{array}$ & Mean & $\begin{array}{l}\text { Standard } \\
\text { error }\end{array}$ \\
\hline Agricultural GDP, million 2004-6 GHS & $\mathrm{Y}$ & & \\
\hline Total agriculture & $\mathrm{Y}_{\text {tot }}$ & $4,145.59$ & 172.03 \\
\hline Noncocoa subsector & $Y_{\text {non }}$ & $3,584.98$ & 170.64 \\
\hline Cocoa subsector & $Y_{\text {coc }}$ & 560.62 & 26.07 \\
\hline Agricultural expenditure, million 2006 GHS & agEXP & & \\
\hline Noncocoa subsector & $\operatorname{agEXP}_{\text {non }}$ & 103.98 & 7.43 \\
\hline Cocoa subsector & $\operatorname{agEXP} P_{\text {coc }}$ & 211.02 & 22.25 \\
\hline Agricultural capital stock, million 2006 GHS & agSTK & & \\
\hline Noncocoa subsector & agSTK non $_{\text {non }}$ & $2,276.08$ & 46.40 \\
\hline Cocoa subsector & agSTK $_{\mathrm{coc}}$ & $2,729.56$ & 212.88 \\
\hline \multicolumn{4}{|l|}{ Variables in expenditure equations only } \\
\hline GDP per capita, 2006 GHS & GDPPCAP & 739.15 & 17.84 \\
\hline Real foreign exchange, GHS/US $\$ 1$ & FOREX & 1.84 & 0.15 \\
\hline Official development assistance, share of GDP & ODAGDP & 6.17 & 0.57 \\
\hline Type of government: 1966, 1972, 1979, 1982 & GOVTYP & 0.08 & \\
\hline $\begin{array}{l}\text { Minister of finance: } 1966,1969,1972,1978, \\
1979,1980,1982,1995,2001,2005,2007,2009\end{array}$ & MINFIN & 0.23 & \\
\hline $\begin{array}{l}\text { Minister of agriculture: } 1962,1963,1966,1967 \text {, } \\
\text { 1968, 1969, 1971, 1972, 1973, 1977, 1979, 1980, } \\
\text { 1981, 1982, 1984, 1985, 1986, 1992, 1996, 1997, } \\
1998,2001,2005,2009\end{array}$ & MINAG & 0.46 & \\
\hline $\begin{array}{l}\text { Chief executive officer of Cocobod: 1973, 1976, } \\
\text { 1978,1980,1984,1992, 1994, 1997, 2001, 2002, } \\
\text { 2006, 2009 }\end{array}$ & CEOCOB & 0.23 & \\
\hline $\begin{array}{l}\text { Agricultural sector policy: 1972, 1983, 1988, } \\
\text { 1991, 1994, 1997, } 2007\end{array}$ & AGPOL & 0.13 & \\
\hline $\begin{array}{l}\text { Cocoa subsector policy: 1966, 1977, 1984, 1993, } \\
1996,1999,2004\end{array}$ & COPOL & 0.13 & \\
\hline $\begin{array}{l}\text { Agriculture expenditure review: 1977, } \\
\text { 1997, } 2006\end{array}$ & AGPER & 0.06 & 0.05 \\
\hline \multicolumn{4}{|l|}{$\begin{array}{l}\text { Variables in both expenditure and output } \\
\text { equations }\end{array}$} \\
\hline Government total expenditure, share of GDP & TOTEXP & 22.49 & 1.02 \\
\hline Share of cocoa price (f.o.b.) received by farmers & SHCOCPR & 53.22 & 5.16 \\
\hline $\begin{array}{l}\text { Openness of economy, ratio of value of imports } \\
\text { to exports }\end{array}$ & OPENECON & 1.31 & 0.03 \\
\hline Population growth, \% & POPGROW & 2.59 & 0.06 \\
\hline $\begin{array}{l}\text { Monetary policy: } 1967,1971,1975,1977,1980 \text {, } \\
1982,1983,1993,2006,2007\end{array}$ & MONPOL & 0.19 & \\
\hline Rainfall, mm & RAINTOT & $1,177.36$ & 20.13 \\
\hline Rainfall, monthly coefficient of variation & RAINCOV & 70.05 & 0.92 \\
\hline $\begin{array}{l}\text { Variables in output equations only } \\
\text { Ratio of cocoa price index to fertilizer price } \\
\text { index }\end{array}$ & COCFERT & 1.51 & 0.11 \\
\hline $\begin{array}{l}\text { Ratio of agriculture price index to fertilizer } \\
\text { price index }\end{array}$ & AGRFERT & 1.58 & 0.07 \\
\hline
\end{tabular}


Table 7.5. Continued

\begin{tabular}{|c|c|c|c|}
\hline Variable & $\begin{array}{l}\text { Name in } \\
\text { model }\end{array}$ & Mean & $\begin{array}{l}\text { Standard } \\
\text { error }\end{array}$ \\
\hline Ratio of gold price index to cocoa price index & GOLDCOC & 0.53 & 0.05 \\
\hline $\begin{array}{l}\text { Ratio of gold price index to agriculture price } \\
\text { index }\end{array}$ & GOLDAGR & 0.45 & 0.04 \\
\hline $\begin{array}{l}\text { Ratio of area under cocoa to area under } \\
\text { noncocoa }\end{array}$ & SHCOAREA & 0.07 & 0.00 \\
\hline
\end{tabular}

Note: For the exogenous or predetermined variables, the lagged values are used (this includes the lagged values of the endogenous variables). The exogenous categorical variables take on the value of 1 in 1961 and subsequent years until a change in regime or an incident takes place and then the value goes up to 2 , then 3 , 4, etc., for the respective years indicated. For these, the mean values represent the frequency of change in the fifty-two years of the data. All continuous variables are transformed by natural logarithm, excluding those measured as indexes or as percentages or shares. Then the first differences of all transformed or nontransformed variables are used in the estimation.

Source: Author's calculation based on various data sources (see Table 7A.2 for details).

variable is measured by the dummy variable for the three years following the year $(1977,1997,2006$, and 2012) in which an agriculture public expenditure review was undertaken (agPER). For these shock variables, they take on the value of 1 in 1961 and subsequent years until a change in regime or an incident takes place and then the value goes up to 2 , then 3 , 4 , etc., for the respective years indicated in Table 7.5. Taking the variable AGPOL as an example, which is used for the general evolution of policies, institutions, infrastructure etc., it represents change occurring at successive time periods: 1961-1971 $=1$ (as the baseline following Independence), 1972-1982 = 2 (period after the first agriculture-sector-specific strategy embodied in the operation Feed Yourself), $1983-1990=3$ (start of the Economic Recovery Program), 1988-1990 = 4 (start of decentralization), 1991-9 = 5 (for complete pullout of the direct government involvement in production, stoppage of subsidies, etc.), 1994-5 = 6 (establishment of the District Assembly Common Fund), 1997-2006 = 7 (incorporation of the district agricultural development units into the District Assembly), and 2007-12 = 8 (for PRSP, CAADP, reintroduction of subsidies, etc.). For the MONPOL, we combine major incidents in currency change (1967, 1982, 2007), GDP rebasing (1993 and 2008), and drought (1971, 1977,1980 , and 1983). A measure of the openness of the economy (OPENECON) is used to test the efficiency or compensatory theory of the effects of globalization (Rodrik 1998; Garrett 2001). Other variables include total government expenditure (TOTEXP, which is used to capture overall budget constraint), foreign exchange rate (FOREX), official development assistance 
(ODAGDP), share of cocoa prices received by farmers (SHCOCPR), and population growth (POPGROW). Rainfall, measured as total annual amount (RAINTOT) and monthly coefficient of variation (RAINCOV), obtained from HarvestChoice (2015) are used to capture the effect of weather shocks.

For variables captured by $Z 1$ and $Z 2$, that is, factors affecting inputs and output, they include several of those described above such as OPENECON, TOTEXP, MONPOL, SHCOCPR, POPGROW, RAINTOT, and RAINCOV. In addition, we include four variables on relative price indexes (cocoa/fertilizer, agriculture/fertilizer, gold/cocoa, and gold/agriculture) and ratio of cocoa area to noncocoa area.

The two sets of equations, $5 \mathrm{a}$ and $5 \mathrm{~b}$ and then $6 \mathrm{a}$ and $6 \mathrm{~b}$, were estimated using simultaneous equations modeling (SEM) methods. A number of estimation issues had to be addressed and these are discussed in Appendix 7B. The model results and statistical tests are also presented and discussed in Appendix 7B, along with tables showing the regression results. A brief discussion of the general results is provided there.

\subsubsection{Estimated elasticities or growth effects of public agricultural spending}

Whereas, the estimated elasticities of government spending on output in the noncocoa subsector are mostly positive and statistically significant, those with respect to Cocobod spending on output in the cocoa subsector are mostly insignificant with a mix of positive and negative effects. Considering the effect of the disaggregated spending on total agricultural output, for example, both expenditure and capital stock in the noncocoa subsector have direct positive and statistically significant effects, with elasticities in the range of $0.10-0.13$ for expenditures and 0.9-1.21 for stocks. However, the total effect after accounting for an indirect effect arising from an increase in the stock of capital reducing the government's spending leads to a smaller elasticity estimates (0.34-0.48) that are not statistically significant. On the other hand, the direct or total effect of expenditures and stocks in the cocoa subsector on total output is not statistically significant. A similar pattern is observed for the estimated elasticities of subsector-disaggregated expenditures and stocks on subsectordisaggregated output, with some mixed results. For the noncocoa subsector, the direct effect of expenditures is not statistically significant, but the direct effect of stocks is statistically significant $(0.7-1.1)$, and so is the total effect (0.7-1.0). For the cocoa subsector, the direct effect of expenditures is significant (0.5-0.7), but the direct effect of stocks is not statistically significant, and the total effect too, which is negative, is not statistically significant. Because of 
the larger expenditure-to-output ratios in the cocoa subsector compared to the noncocoa subsector (which is about twenty times larger on average in 1961-2012 and more in recent years-see Table 7.2), these estimated elasticities translate into higher marginal effects or returns to spending in the noncocoa subsector than in the cocoa subsector.

Because the financial management and expenditure determination processes are different for the two subsectors, there is no direct way of reallocating expenditures on the cocoa subsector to the noncocoa subsector as the results may imply. Expenditures on the noncocoa subsector by the government derive from the national budget that is approved by parliament, whereas the expenditures on cocoa by the Cocobod are directly financed from the proceeds of cocoa exports. But the two are linked since the government revenue and spending depends on the tax on cocoa exports and profits, both of which in turn depend on the share of cocoa f.o.b. prices that is given to farmers (SHCOCPR in the model). As expected, SHCOCPR has a negative effect on expenditures in both the noncocoa and cocoa subsectors. But SHCOCPR has a relatively larger positive effect on output. Therefore, increasing the share of cocoa f.o.b. prices that is given to farmers may be an indirect way of reallocating expenditures to boost output and raise the returns to spending in especially the cocoa subsector.

One reason government spending has had a weaker long-term impact on noncocoa output is because the government tended to reduce its spending over time as the capital stock increased, leading to a negative feedback effect in the model. If the government were to change this behavior in the future and focus more on building up the capital stock in the noncocoa sector, then the returns to its investment would be enhanced.

Results of the aggregate analysis also mask differences between the two subsectors in terms of the importance of other variables. Detailed results are again discussed in Appendix 7B, but of particular interest are the following. With respect to total agricultural output, for example, the main statistically significant variables are OPENECON (-), SHCOCPR (+), and MONPOL (-). These suggest that globalization (importing more relative to exports) has had a dampening effect on agricultural growth. The same with MONPOL, which is associated with incidents of currency change, GDP rebasing, and drought. Giving a higher share of the cocoa f.o.b. price to farmers (SHCOCPR) has a boosting effect, perhaps by increasing farmers' investment in the agricultural sector. The results by subsector suggest that whereas the negative effect of MONPOL derives from both subsectors, the negative effect of OPENECON derives mostly from the noncocoa subsector and the positive effect of SHCOCPR derives mostly from the cocoa subsector. 
In general, there is a low number of variables that have a statistically significant effect on expenditures in the cocoa subsector (see Table 7B.2a and Table 7B.3a), which suggest that the expenditure determination process in the cocoa subsector as modeled here may not have been realistic. With a likely omitted variables problem, any resulting bias in the cocoa subsector expenditure equation may have been transmitted to the other equations. Further research is needed on this. Also, there are other objectives such as food security and foreign exchange earnings beyond production that will be useful to include in the model. Thus, further disaggregation and analysis of expenditures in the noncocoa subsector into, for example, export and food subgroups is needed, in addition to disaggregated data on foreign exchange earnings and food imports.

\subsubsection{Relative Returns to Public Expenditure by Type of Spending, 2000-6}

Beyond differentiating between spending on the cocoa and noncocoa subsectors, the previous analysis sheds little light on which types of public spending are the most productive, and hence which types of spending should be prioritized for agricultural growth. The available data for Ghana limit the level of analysis that can be undertaken, but Benin et al. (2012) have estimated the marginal returns to public spending on agriculture verses other sectors, including education, health, and rural roads. Their analysis follows the same basic conceptual framework as described earlier, but with a different empirical approach. Unlike the reduced-form, single-equation approach used in the preceding analysis, Benin et al. (2012) estimate a system of equations consisting of a household agricultural production function and separate equations to explain the levels of farm investment and public agriculture expenditure. The production function and farm investment are estimated using household level data from the 2005/6 GLSS household survey, and the agricultural public expenditures and capital stocks are calculated using district- and regiondisaggregated public expenditure data from 2000 to 2006. The effect of public spending on the other sectors of rural roads, education, and health were modeled via the impact of rural road density, literacy rate, and access to a health facility, respectively, on farm investments and agricultural production.

Their results show that an increase in public spending on the agricultural sector by 1 percent is associated with a $0.22-0.35$ percent increase in households' agricultural productivity (i.e., value of household total agricultural 
production per capita). This translates into very high economic returns. For the marginal Ghana cedi (GHS) spent, GHS3.51-4.15 is returned in terms of increase in agricultural GDP.

Regarding spending on other sectors, greater rural road density-the indicator used for public capital in the sector-is significantly associated with greater household agricultural productivity, with an estimated productivity effect of $0.19-0.26$ percent for a 1 percent increase in the rural road density. ${ }^{4}$

Literacy rate, or the proportion of the population that is literate-the indicator used for public capital in the education sector-has no statistically significant effect. This may seem surprising given the large share of and increment in spending on the education sector (Table 7.4). However, while both net enrollment and adult literacy improved over time at the national level, they declined in rural areas, suggesting that the increase in total public spending on the sector has not benefited the agricultural sector.

The effect of the public capital variables in the health sector is mixed, and is also somewhat surprising. The public capital stock is measured by the proportion of the population living within $1 \mathrm{~km}$ and between $1-5 \mathrm{~km}$ of a health facility, against the comparative base of the population living more than $5 \mathrm{~km}$ away from a health facility. While the association between agricultural productivity and the indicator for those living within $1 \mathrm{~km}$ of a health facility is positive, the level of statistical significance is weak.

As captured in this analysis, it would seem that government spending on agriculture and rural roads have been the best investments for increasing agricultural productivity growth, whilst government spending on education and health does not seem to have translated into measurable agricultural productivity effects. This is concerning given that government spending on health and education has grown rapidly in recent years and (together) accounts for about a quarter percent of the total expenditures (Table 7.4), while spending on agriculture and rural roads has remained flat and accounts for less than 5 percent of the total expenditures. The analysis has not attempted to capture the impacts of public spending on the different sectors in the nonagricultural sector or the entire economy, so it is hard to draw strong conclusions on their relative importance for raising overall growth or in reducing overall poverty. Also missing is any disaggregated analysis of the impacts of different kinds of agricultural spending. For example, is it better to

\footnotetext{
4 Estimating the marginal returns to public spending on the nonagricultural sectors was not done as the author did not have data on the relevant expenditures to estimate the relationship between the expenditures and the public capital stocks, as was done for the agricultural sector.
} 
spend more on $\mathrm{R} \& \mathrm{D}$ or irrigation versus other kinds of agricultural spending such as market infrastructure or subsidies? All we know at this point is that spending on the noncocoa subsector gives higher returns than spending on the cocoa subsector. There is a need for more research on this topic.

\subsection{New Directions in Government Spending on Agriculture}

With the reintroduction of fertilizer subsidies in 2007, the government seems to have started paying more attention to the noncocoa subsector, with the introduction of four major subsidy and credit programs being implemented by MoFA. These involve:

- Subsidization of agricultural mechanization services via support to the establishment and operation of Agricultural Mechanization Service Centers (AMSEC)

- Subsidization of fertilizers via the National Fertilizer Subsidy Program

- Establishment and management of block farms that benefit from subsidized mechanization services and inputs (fertilizers, improved seed, and pesticides) and extension services, and

- Stabilization of output prices via the establishment and operation of the National Food Buffer Stock Company (NAFCO).

Food crops are the target, with the major ones including maize grain and seed, rice grain and seed, soybean, sorghum, tomato, and onions. The government spent about GHS 7.9 million each year in 2007 and 2008 on these programs, but the costs have since escalated. Benin et al. (2013) estimated that the combined cost of the fertilizer subsidy, block farming, and AMSEC programs was 25 percent of MoFA's budget in 2010, with the fertilizer subsidy accounting for the bulk. Because of the escalation in the cost, the government was not able to implement the fertilizer program in 2014, though it resumed it in 2015.

Early evidence suggested that the fertilizer subsidy did increase fertilizer use, and farmers who applied fertilizer on their farms obtained higher yields and net income than those who did not use any (Benin et al. 2013). On the basis of that evidence, Benin et al. (2013) projected that the overall future economic return of the program would be positive, with an estimated benefit-cost ratio of 1.7. The same study also found initial benefits from the AMSEC and block 
farming programs, and strong synergies between the benefits of the fertilizer subsidy, AMSEC and block farming programs and the price support program implemented by NAFCO. Benin (2015) found that the AMSEC program has had mixed impact on different outcome indicators-whereas the program has contributed to improving availability of mechanization services, reducing drudgery, and raising yield, it has had no impact on the change in the prices paid by farmers for the services used and the change in the amount of area plowed. The initial gains from these programs is reflected in the positive growth rate (3.6 percent per annum) over 2009-12 in agriculture output per hectare for the noncocoa subsector (Table 7.2). The relative contribution of the four programs to this overall productivity performance is unknown, however. Given the weak relationship between fertilizer use and yields found in other chapters of this book, the rationale for spending the bulk of the funds on the fertilizer subsidy program is questioned. The evidence in the other chapters shows that fertilizer use is related more to maintaining soil fertility as fallow periods are shortened rather than to intensify land productivity. Similarly, the analysis of AMSEC in Chapter 9 also raises questions as to whether the reliance on heavy-duty tractors and equipment is a sound intervention for promoting agricultural mechanization in Ghana. While this chapter has demonstrated the need to rebalance public spending towards the noncocoa subsector, and the government's ongoing attempt to do that must be welcomed, serious concerns remain about whether the current approach is likely to be successful or cost effective.

\subsection{Conclusions}

The government's public spending on agriculture has fallen short of 10 percent of its total expenditure in most years since 1961. In recent times, the share was only 2.1 percent during 2001-8 and 2.8 percent during 2009-12. This is low even by African standards, especially as it includes food staples, and in terms of fulfilling the Maputo Declaration target of 10 percent. This excludes the cocoa subsector, which is managed by the Cocobod (a state-owned enterprise). Relative to the respective output of the subsector, the amount spent by the Cocobod on the cocoa subsector far outweighs the amount spent by the government on the noncocoa subsector. One reason for the low share of government spending on the noncocoa subsector is that the tax on cocoa exports sustains a lot of the spending in the cocoa subsector. This is consistent with the finding of a negative effect of the share of cocoa prices received by farmers on expenditure in the noncocoa subsector. 
Overall, public spending on agriculture has given favorable returns in Ghana, and better than some other public investments in rural areas. One study, for example, found that on the margin, each Ghanaian cedi (GHS) spent on agriculture during 2000-6 returned GHS3.51-4.15 in terms of increases in agricultural GDP, and that government spending on agriculture and rural roads had bigger marginal impacts on agricultural productivity than government spending on education and health (Benin et al. 2012). The detailed analysis reported in this chapter for 1961-2000 also found significant and positive direct impacts from public spending in agriculture, but with more powerful and statistically significant impacts in the noncocoa than the cocoa subsector. It was also found that government spending in the noncocoa subsector was negatively related to the size of the capital stock, and this had a negative and indirect impact on the returns. If in the future the government were to change its behavior and attach more importance to building up the capital stock, this would enhance the long-run returns on its investments.

Although the expenditure-to-GDP ratio is much higher in the cocoa than in the noncocoa subsector, there is no direct way of reallocating expenditures from the cocoa to the noncocoa subsector as the expenditures on cocoa are directly financed by the proceeds of cocoa exports. The government simply needs to boost its spending on the noncocoa subsector. In 2007 the government launched several subsidy programs to help grow the noncocoa subsector. These include the fertilizer subsidy program, and the AMSEC and block farming programs, as well as a price support program implemented by NAFCO. The cost of these programs was initially modest at GHS7.5 million per year in 2007 and 2008, but had escalated to 25 percent of MoFA's budget in 2010, and seems likely to increase to about half MoFA's budget by 2020. Unfortunately, the available evidence does not show these programs to be generating the full benefits that were expected, and there is need to reevaluate them to ascertain whether this is the best way to spend available public resources to promote agricultural growth.

In terms of its total budget, the government spends far more on health and education than on agriculture and rural roads. Analysis shows that government spending on agriculture and rural roads has been the best investment for increasing agricultural productivity growth, whilst government spending on education and health does not seem to have translated into measurable agricultural productivity effects. The analysis has not attempted to capture the impacts of this public spending on overall growth or poverty reduction, so it is hard to draw strong conclusions. Also missing is any disaggregated analysis of the impacts of different kinds of agricultural spending, for example $\mathrm{R} \& \mathrm{D}$ or irrigation versus other kinds of agricultural spending. There is a need for more research on this topic. 


\section{APPENDIX}

7A: Data Sources on Public Expenditures in Ghana, 1961-2012

Table 7A.1. Data and sources on public expenditures in Ghana, 1961-2012

\begin{tabular}{|c|c|c|c|c|c|c|}
\hline \multirow[t]{2}{*}{ Year } & \multicolumn{2}{|c|}{ Total government expenditure } & \multicolumn{2}{|c|}{ Agriculture expenditure (million GHS) } & \multirow{2}{*}{$\frac{\text { Deflator }^{\mathrm{d}}}{2006=100}$} & \multirow{2}{*}{$\begin{array}{l}\text { Agriculture expenditure data sources } \\
(\mathrm{N}=\text { noncocoa, } \mathrm{C}=\text { cocoa })\end{array}$} \\
\hline & Million GHS ${ }^{\mathrm{a}}$ & Capital $(\%)^{\mathbf{b}}$ & Noncocoa subsector & Cocoa subsector $^{c}$ & & \\
\hline 1961 & 0.023 & 39.1 & 0.0028 & 0.0022 & 0.0017 & Stryker (1990) \\
\hline 1962 & 0.025 & 40.7 & 0.0021 & 0.0020 & 0.0017 & Stryker (1990) \\
\hline 1963 & 0.027 & 39.3 & 0.0025 & 0.0021 & 0.0019 & Stryker (1990) \\
\hline 1964 & 0.033 & 38.8 & 0.0027 & 0.0022 & 0.0020 & Stryker (1990) \\
\hline 1965 & 0.036 & 39.2 & 0.0039 & 0.0038 & 0.0024 & Stryker (1990) \\
\hline 1966 & 0.027 & 24.2 & 0.0027 & 0.0017 & 0.0026 & Stryker (1990) \\
\hline 1967 & 0.031 & 22.0 & 0.0025 & 0.0018 & 0.0025 & Stryker (1990) \\
\hline 1968 & 0.037 & 18.3 & 0.0026 & 0.0020 & 0.0028 & Stryker (1990) \\
\hline 1969 & 0.044 & 19.0 & 0.0029 & 0.0016 & 0.0031 & Stryker (1990) \\
\hline 1970 & 0.047 & 23.0 & 0.0030 & 0.0019 & 0.0032 & Stryker (1990) \\
\hline 1971 & 0.050 & 20.6 & 0.0034 & 0.0034 & 0.0034 & Stryker (1990) \\
\hline 1972 & 0.054 & 17.9 & 0.0039 & 0.0042 & 0.0039 & Stryker (1990) \\
\hline 1973 & 0.077 & 22.1 & 0.0042 & 0.0062 & 0.0047 & Stryker (1990) \\
\hline 1974 & 0.114 & 25.2 & 0.0076 & 0.0075 & 0.0059 & Stryker (1990) \\
\hline 1975 & 0.150 & 29.5 & 0.0107 & 0.0124 & 0.0076 & Stryker (1990) \\
\hline 1976 & 0.200 & 31.9 & 0.0192 & 0.0165 & 0.0097 & Stryker (1990) \\
\hline 1977 & 0.306 & 22.7 & 0.0426 & 0.0114 & 0.0163 & Stryker (1990) \\
\hline 1978 & 0.374 & 20.3 & 0.0476 & 0.0311 & 0.0282 & Stryker (1990) \\
\hline 1979 & 0.409 & 16.9 & 0.0490 & 0.0427 & 0.0389 & Stryker (1990) \\
\hline 1980 & 0.467 & 10.5 & 0.0570 & 0.0685 & 0.0588 & N=IFPRI (2015), C=Stryker (1990) \\
\hline 1981 & 0.772 & 14.8 & 0.0940 & 0.1015 & 0.1032 & $\mathrm{~N}=$ IFPRI (2015), C=Stryker (1990) \\
\hline 1982 & 0.953 & 8.7 & 0.1020 & 0.1290 & 0.1320 & N=IFPRI (2015), C=Stryker (1990) \\
\hline 1983 & 1.476 & 8.1 & 0.1171 & 0.2178 & 0.2944 & N=IFPRI (2015), C=Stryker (1990) \\
\hline
\end{tabular}




\begin{tabular}{|c|c|c|c|c|c|c|}
\hline 1984 & 2.669 & 12.6 & 0.1320 & 0.4641 & 0.3984 & N=IFPRI (2015), C=Stryker (1990) \\
\hline 1985 & 4.576 & 13.1 & 0.2830 & 0.8321 & 0.4807 & N=IFPRI (2015), C=Stryker (1990) \\
\hline 1986 & 7.066 & 11.9 & 0.3200 & 1.2524 & 0.6811 & N=IFPRI (2015), C=Stryker (1990) \\
\hline 1987 & 10.213 & 19.7 & 0.4630 & 1.6651 & 0.9481 & $\mathrm{~N}=$ IFPRI (2015), C=linear interpolation \\
\hline 1988 & 14.390 & 19.4 & 0.5000 & 2.1168 & 1.2648 & $\mathrm{~N}=\mathrm{IFPRI}$ (2015), C=linear interpolation \\
\hline 1989 & 19.647 & 21.9 & 0.9140 & 2.5817 & 1.6227 & $\mathrm{~N}=$ IFPRI (2015), C=linear interpolation \\
\hline 1990 & 25.447 & 20.9 & 1.0438 & 3.2105 & 2.1284 & $\mathrm{~N}=\mathrm{IFPRI}(2015), \mathrm{C}=\mathrm{IMF}(1998)$ \\
\hline 1991 & 34.026 & 20.8 & 1.2378 & 4.0886 & 2.5550 & $\mathrm{~N}=\mathrm{IFPRI}(2015), \mathrm{C}=\mathrm{IMF}(1998)$ \\
\hline 1992 & 49.881 & 24.1 & 1.9815 & 4.7814 & 2.8399 & $\mathrm{~N}=\mathrm{IFPRI}(2015), \mathrm{C}=\mathrm{IMF}(2000)$ \\
\hline 1993 & 81.353 & 19.1 & 2.8449 & 7.0119 & 3.7418 & $\mathrm{~N}=\mathrm{IFPRI}(2015), \mathrm{C}=\mathrm{IMF}(2000)$ \\
\hline 1994 & 177.231 & 25.8 & 2.9427 & 6.0667 & 4.8691 & $\mathrm{~N}=\mathrm{CAGD}$ (2011), C=IMF (2000) \\
\hline 1997 & 464.865 & 18.2 & 6.5785 & 20.7430 & 11.6350 & $\mathrm{~N}=\mathrm{CAGD}(2011), \mathrm{C}=\mathrm{IMF}(2000)$ \\
\hline 1998 & 560.744 & 18.6 & 7.8291 & 29.5062 & 13.6186 & $\mathrm{~N}=\mathrm{CAGD}(2011), \mathrm{C}=\mathrm{IMF}(2000)$ \\
\hline 1999 & 656.622 & 27.9 & 17.7458 & 30.4868 & 15.5213 & $\mathrm{~N}=\mathrm{CAGD}(2011), \mathrm{C}=\mathrm{IMF}(2000)$ \\
\hline 2000 & 752.500 & 36.9 & 17.9186 & 46.5510 & 19.7477 & $\mathrm{~N}=\mathrm{CAGD}$ (2011), C=IMF (2005) \\
\hline 2001 & $1,199.760$ & 51.6 & 14.7664 & 83.0808 & 26.6235 & $\mathrm{~N}=$ MoFA (2013), C=Kolavalli et al. (2012) \\
\hline 2002 & $1,277.780$ & 43.4 & 18.3890 & 107.9965 & 32.6985 & N=MoFA (2013), C=Kolavalli et al. (2012) \\
\hline 2003 & $1,880.200$ & 48.4 & 26.3825 & 190.3620 & 42.0845 & $\mathrm{~N}=$ MoFA (2013), C=Kolavalli et al. (2012) \\
\hline 2004 & $2,603.466$ & 53.5 & 45.7670 & 271.3823 & 48.1237 & $\mathrm{~N}=$ MoFA (2013), C=Kolavalli et al. (2012) \\
\hline 2005 & $3,070.353$ & 48.9 & 78.9841 & 300.8731 & 55.3247 & $\mathrm{~N}=$ MoFA (2013), C=Kolavalli et al. (2012) \\
\hline 2006 & $4,056.891$ & 31.5 & 90.6267 & 340.0949 & 100.0000 & N=MoFA (2013), C=Kolavalli et al. (2012) \\
\hline 2007 & $5,661.918$ & 41.3 & 141.4683 & 418.8755 & 116.2760 & $\mathrm{~N}=$ MoFA (2013), C=Kolavalli et al. (2012) \\
\hline 2008 & $7,407.220$ & 43.4 & 256.6725 & 521.9458 & 139.7663 & $\mathrm{~N}=$ MoFA (2013), C=Kolavalli et al. (2012) \\
\hline 2009 & $8,869.230$ & 53.9 & 220.6086 & 872.2741 & 163.8475 & $\mathrm{~N}=$ MoFA (2013), C=Kolavalli et al. (2012) \\
\hline 2010 & $12,173.835$ & 44.1 & 327.9592 & $1,257.9316$ & 191.0390 & $\mathrm{~N}=$ MoFA (2013), C=Kolavalli et al. (2012) \\
\hline 2011 & $13,829.000$ & 38.2 & 406.5289 & $1,368.8934$ & 217.6239 & $\mathrm{~N}=\mathrm{MoFA}(2013), \mathrm{C}=\mathrm{GCB}$ (2013) \\
\hline 2012 & $22,675.000$ & 15.8 & 667.0152 & $1,423.1870$ & 250.7148 & $\mathrm{~N}=\mathrm{CAGD}(2013), \mathrm{C}=\mathrm{GCB}(2013)$ \\
\hline
\end{tabular}

Notes: Expenditure data prior to 2007 were mostly in the old currency units (GHC), which were divided by 10,000 to obtain the new currency equivalent (GHS).

${ }^{a}$ Data series on total government expenditure were compiled from three sources: 1961-1979 from Stryker (1990), 1980-2010 from IFPRI (2015), and 2011-2012 from CAGD (2014). These total expenditures do not include expenditures on cocoa that were incurred by the Ghana Cocoa Board, which is an autonomous public corporation. In the analysis therefore, we add the expenditures on cocoa to total government expenditure to obtain total public expenditure.

b Data series on total capital expenditures were compiled from two sources: 1961-1979 from Stryker (1990) and 1980-2012 from various issues of government finance statistics issued by the Controller of Accountant General's Department (CAGD).

${ }^{c}$ Expenditures on the cocoa were reported for financial years from October to September. We use the last year in the financial year as the calendar year to compile the data (e.g., 1978 for 1977/1978).

${ }^{d}$ Data series on the deflator is calculated by dividing GDP in current GHS by GDP in constant 2006 GHS, which were obtained from the World Bank (2015). 
Table 7A.2. Sources of data for the variables used in the regression analysis, 1961-2012

\begin{tabular}{|c|c|}
\hline Variable & Source of data \\
\hline $\begin{array}{l}\text { Agricultural GDP, million } 2006 \text { GHS }(Y) \\
\text { Total agriculture }\left(\mathrm{Y}_{\text {tot }}\right) \\
\text { Noncoca subsector }\left(\mathrm{Y}_{\text {non }}\right) \\
\text { Cocoa subsector }\left(\mathrm{Y}_{\mathrm{coc}}\right)\end{array}$ & GSS (2016), FAO (2016) \\
\hline $\begin{array}{l}\text { Agricultural expenditure, million } 2006 \text { GHS (agEXP) } \\
\text { Noncoca subsector }\left(\mathrm{agEXP}_{\text {non }}\right) \\
\text { Cocoa subsector }\left(\mathrm{agEXP}_{\mathrm{coc}}\right) \\
\text { Agricultural capital stock, million } 2006 \text { GHS (agSTK) } \\
\text { Noncoca subsector }\left(\mathrm{agSTK}_{\text {non }}\right) \\
\text { Cocoa subsector }\left(\mathrm{agSTK}_{\mathrm{coc}}\right)\end{array}$ & $\begin{array}{l}\text { Stryker (1990), IMF (1998, } \\
\text { 2000, 2005), Kolavalli et al. } \\
\text { (2012), MoFA (2013), GCB } \\
\text { (2013), CAGD (2011, 2013, } \\
\text { 2014), IFPRI (2015), World } \\
\text { Bank (2015) }\end{array}$ \\
\hline $\begin{array}{l}\text { Variables in expenditure equations only } \\
\text { GDP per capita, } 2006 \text { GHS (GDPPCAP) } \\
\text { Real foreign exchange, GHS/US\$1 (FOREX) } \\
\text { Official development assistance, share of GDP } \\
\text { (ODAGDP) }\end{array}$ & $\begin{array}{l}\text { GSS (2016), FAO (2016) } \\
\text { World Bank (2016a) } \\
\text { World Bank (2016a) }\end{array}$ \\
\hline $\begin{array}{l}\text { Type of government (GOVTYP): } \\
\text { Minister of finance (MINFIN): } \\
\text { Minister of agriculture (MINAG): } \\
\text { Chief executive officer of Cocobob (CEOCOB): } \\
\text { Agricultural sector policy (AGPOL): } \\
\text { Cocoa subsector policy (COPOL): } \\
\text { Agriculture expenditure review (AGPER): 1977, } \\
\text { 1997, } 2006\end{array}$ & $\begin{array}{l}\text { Authors, based on historical } \\
\text { accounts from various sources }\end{array}$ \\
\hline $\begin{array}{l}\text { Variables in both expenditure and output equations } \\
\text { Government total expenditure, share of GDP (TOTEXP) } \\
\text { Share of cocoa price (f.o.b.) received by farmers } \\
\text { (SHCOCPR) }\end{array}$ & $\begin{array}{l}\text { See sources on expenditure } \\
\text { above }\end{array}$ \\
\hline $\begin{array}{l}\text { Openness of economy, ratio of value of imports to } \\
\text { exports (OPENECON) }\end{array}$ & World Bank (2016a) \\
\hline $\begin{array}{l}\text { Population growth, \% (POPGROW) } \\
\text { Monetary policy (MONPOL): } \\
\text { Rainfall, mm (RAINTOT) } \\
\text { Rainfall, monthly coefficient of variation (RAINCOV) }\end{array}$ & $\begin{array}{l}\text { World Bank }(2016 \mathrm{a}) \\
\text { See sources on policies } \\
\text { HarvestChoice }(2015)\end{array}$ \\
\hline $\begin{array}{l}\text { Variables in output equations only } \\
\text { Ratio of cocoa price index to fertilizer price index } \\
\text { (COCFERT) } \\
\text { Ratio of agriculture price index to fertilizer price index } \\
\text { (AGRFERT) } \\
\text { Ratio of gold price index to cocoa price index } \\
\text { (GOLDCOC) } \\
\text { Ratio of gold price index to agriculture price index } \\
\text { (GOLDAGR) }\end{array}$ & World Bank (2016b) \\
\hline $\begin{array}{l}\text { Ratio of area under cocoa to area under noncocoa } \\
\text { (SHCOAREA) }\end{array}$ & FAO (2016) \\
\hline
\end{tabular}

Source: Author's compilation based on cited sources. 


\title{
7B: Regression Results on Impact of Agricultural Public Expenditure on Agricultural Output, 1961-2012
}

\author{
Brief Discussion of Estimation and Results
}

The model presented in the main text (equations $5 \mathrm{a}, 5 \mathrm{~b}, 6 \mathrm{a}$ and $6 \mathrm{~b}$ ) was estimated for the agricultural sector as a whole and then separately for the cocoa and noncocoa subsectors, using simultaneous equations modeling (SEM) estimation techniques. Table 7.5 in the main text presented the specific variables used and their descriptive statistics. The same set of variables were used in the aggregate and disaggregated analysis, with the exception of a few variables that were included or excluded as they were hypothesized to be subsector specific or affecting expenditures or output only.

Two major estimation issues were addressed. First, in applying SEM methods, the error terms $e_{s t}$ are assumed to have a mean of zero and constant variance, and be uncorrelated with the explanatory variables and uncorrelated across equations or over time (Zellner and Theil 1962; Greene 1993). For the latter, autocorrelation, we test the null hypothesis of no autocorrelation using the Harvey Lagrange multiplier (LM) test (Harvey 1990; Judge et al. 1985), separately for each equation and then for the overall system. The second issue is identification of the system, which we use exclusion restrictions to accomplish. The rule of thumb for using exclusion restrictions is that the number of exogenous variables excluded from equation q must be at least as large as the number of endogenous variables included in equation q. In addition to the explanatory factors discussed earlier, we use the lagged value of $Y$ as its instrument in some model specification to assess the strength of identification.

As we are using time-series data, another issue to deal with is stationarity of especially the dependent variables, which we find to be nonstationary in their levels but stationary in their first differences. Therefore, we estimate the first-difference equations. This means that the initial constant term $a$ drops out and is replaced by a new one since $t-(t-1)=1$. In general, first differencing helps address expenditure endogeneity due to omitted timeinvariant factors such as agroclimatic conditions that are fixed over time (Fan, Hazell, and Thorat 2000). Also, differencing can address expenditure endogeneity due to simultaneity if expenditure decisions are driven by levels, but not changes in the hypothesized outcome, or agricultural output in this case. The drawback of differencing, however, is that it could remove the long-term effect of expenditures whose benefits typically materialize with a lag rather than contemporaneously (Hsiao 1986). All continuous variables are transformed by natural logarithm so that their estimated coefficients are interpreted directly as elasticities. Then, the elasticity of agricultural output with respect to public agriculture expenditure is obtained as:

$$
\vartheta_{s}=\hat{\beta}_{s}+\hat{\gamma}_{s} .
$$

The stationarity test results are presented in Table 7B.1. The results for the agricultural sector as a whole are presented in Tables 7B.2a for subsector expenditure equations and $7 \mathrm{~B} .2 \mathrm{~b}$ for the aggregate output equations. This is followed by the estimation for the separate subsectors in Table 7B.3a for the subsector expenditure equations and 7B.3b for the subsector output equations. In each set of estimation, we use different model specifications in terms of allowing the $a g S T K_{t}$ in one subsector to be a determinant of $a g E X P_{t}$ or $Y_{t}$ in the other subsector.

Stationarity test results for the dependent variables: Details of the stationarity test results for the dependent variables shown in Table 7B.1 suggest that unit root is a problem with the 
Table 7B.1. Stationarity test results for level and first difference of dependent variables, 1961-2012

\begin{tabular}{|c|c|c|c|c|c|}
\hline \multirow[t]{2}{*}{ Variable } & \multirow[t]{2}{*}{ Unit root test } & \multicolumn{2}{|c|}{ Level } & \multicolumn{2}{|c|}{ First difference } \\
\hline & & Test statistic & $p$-value & Test statistic & $p$-value \\
\hline \multirow[t]{2}{*}{$a g E X P_{\text {non }}$} & $\mathrm{ADF}$ & -1.51 & 0.827 & $-7.78^{\star * \star}$ & 0.000 \\
\hline & $\mathrm{PP}$ & -1.35 & 0.873 & $-7.89^{* * *}$ & 0.000 \\
\hline \multirow[t]{2}{*}{$a g E X P_{c o c}$} & $\mathrm{ADF}$ & -3.06 & 0.115 & $-8.28^{\star * *}$ & 0.000 \\
\hline & $\mathrm{PP}$ & $-3.15^{\star}$ & 0.095 & $-8.44^{\star * *}$ & 0.000 \\
\hline \multirow[t]{2}{*}{$Y_{\text {tot }}$} & $\mathrm{ADF}$ & -2.74 & 0.219 & $-7.26^{* * *}$ & 0.000 \\
\hline & $\mathrm{PP}$ & -2.66 & 0.253 & $-7.45^{\star * *}$ & 0.000 \\
\hline \multirow{2}{*}{$Y_{\text {non }}$} & $\mathrm{ADF}$ & -2.65 & 0.259 & $-7.08^{\star * *}$ & 0.000 \\
\hline & $\mathrm{PP}$ & -2.57 & 0.292 & $-7.14^{\star \star *}$ & 0.000 \\
\hline \multirow[t]{2}{*}{$Y_{c o c}$} & $\mathrm{ADF}$ & $-3.14^{\star}$ & 0.097 & $-7.25^{\star * *}$ & 0.000 \\
\hline & PP & $-3.32^{\star}$ & 0.064 & $-7.28^{\star \star *}$ & 0.000 \\
\hline
\end{tabular}

Note: See Table 7A.2 for detailed descriptions of variables. ADF $=$ augmented Dickey-Fuller (Dickey and Fuller 1979). PP = Phillips-Perron (Phillips and Perron 1988). ${ }^{*},{ }^{* *}$, and ${ }^{* * *}$ mean the test is statistically significant at the 10,5 , and 1 percent level, respectively.

Source: Authors' model results.

level measures but not the first differences. The exceptions are in the cocoa subsector where the levels of expenditure and output are weakly stationary. Therefore, the first-difference measures of the variables were used in the estimation to avoid spurious regressions, which are possible when using the level measures of the variables.

Overall model results: The overall model results are strong. The F-statistics for the individual equations and the system are statistically significant at the 1 percent level. Also, the R-squared for the individual equations is within the range of 0.4 and 0.7 , with those for the systems being generally greater, considering the two different measures of the $\mathrm{R}$-squared that is used. Also, the test for the presence of autocorrelation is rejected for the individual equations as well as for the systems. With respect to efficiency in the use of the system of equations, the results are mixed. In the estimation with respect to total agricultural output, efficiency is gained from allowing cross-over effect of agSTK, that is, by allowing the agSTK in one subsector to affect agEXP in the other subsector. This is indicated by rejection of the Breusch-Pagan LM diagonal covariance matrix test, which the null hypothesis is that there is no contemporaneous correlation across the equations (Judge et al. 1985). In the estimation with respect to subsector-disaggregated agricultural output however, there is no efficiency gain when from allowing cross-over effect of agSTK.

Determinants of subsector expenditures: The statistical significant factors and their signs are the same whether estimated jointly with total agricultural output (Table 7B.2a) or with subsector-disaggregated output (Table 7B.3a). Subsector agricultural capital stock, agSTK , has a negative effect on its respective subsector agricultural expenditure, agEXP ${ }_{s}$. The crossover effect is positive, but only statistically significant for agSTK $\mathrm{goc}_{\mathrm{cos}}$ on $\mathrm{gXX}_{\text {non. }}$ With respect to the other variables, most of their effects are consistent with the literature, although many of them have a statistical significant effect $\operatorname{agEXP}_{\text {non }}$ only. Those with a positive effect are GDPPCAP, TOTEXP, ODAGDP, and MONPOL; whereas FOREX, OPENECON, MINFIN, and RAINCOV have a negative effect. The share of cocoa price received by farmers (SHCOCPR) has a negative effect on both subsector expenditures, which is intuitive, by reducing the amount available to Cocobod to spend and reducing the 
taxes or revenue to the government. Total rainfall (RAINTOT) has a negative effect on agEXP $\mathrm{Coc}_{\mathrm{c}}$ only. The low number of variables having a statistical significant effect on agEXP $_{\text {coc }}$ seems surprising, although it may indicate a different expenditure determination process in the cocoa subsector. More on this later.

Agricultural growth effects of agricultural public expenditure: With respect to total agricultural output (Table 7B.2b), both agEXP ${ }_{\text {non }}$ and $\operatorname{agSTK}_{\text {non }}$ have direct positive and statistical significant effect. This is without the $\operatorname{agSTK}_{\mathrm{s}}-\mathrm{agEXP}_{\mathrm{s}}$ crossover (about 0.1 elasticity for agEXP $\mathrm{Enn}_{\text {non }}$ and 0.9 for agSTK $\mathrm{non}_{\text {n }}$ ) and with the crossover (0.11-0.13 for $\operatorname{agEXP}_{\text {non }}$ and 1.01-1.21 for agSTK non $)$. However, the total elasticity, that is, accounting for the negative indirect effect via agSTK $\mathrm{non}_{\text {on }}$ agEXP $\mathrm{En}_{\text {non }}$ (Table 7B.2a) is not statistically significant (see bottom rows of Table 7B.2b). The effect of agricultural expenditures and stocks in the cocoa subsector on total output is not statistically significant, considering the direct or total effect. With respect to the effect of subsector-disaggregated expenditures and stocks on subsector-disaggregated output, the results shown in Table 7B.3b are mixed: agSTK $_{\text {non }}$ has direct statistical significant effect on $\mathrm{Y}_{\text {non }}(0.7-1.1)$ and agEXP ${ }_{\text {coc }}$ has direct statistical significant effect on $Y_{c o c}(0.5-0.7)$; the crossover effects are not statistically significant; the total effect in the noncocoa subsector is statistically significant (0.7-1.0); but the total effect in the cocoa subsector is not statistically significant.

Might the low number of variables having a statistical significant effect on agEXP $\mathrm{Poc}_{\text {coe }}$ (see Table 7B.2a and Table 7B.3a) have something to do with these results? In the agSTK $\operatorname{agEXP}_{s}$ crossover specification models, we see that agSTK $\mathrm{coc}_{\text {has }}$ a strong positive effect on $\operatorname{agEXP}_{\text {non }}$, but the opposite is not observed-i.e., effect of agSTK $\mathrm{non}_{\text {on }}$ agEXP $\mathrm{Poc}_{\text {co }}$ is not significant. Also, the negative effect of agSTK $\mathrm{non}_{\text {on }} \operatorname{agEXP}_{\text {non }}$ increases with the crossover. Together, these suggest that the expenditure determination process in the cocoa subsector as modeled here may not be realistic, likely suffering from omitted variables bias that has been transmitted to the other equations. ${ }^{5}$ Further research is needed on this.

Influence of other factors on agricultural growth: With respect to total agricultural output (Table 7B.2b), all the variables that have a statistical significant effect are consistent under the different model specifications-excluding or including $\operatorname{agSTK}_{\mathrm{s}}-\mathrm{agEXP}_{\mathrm{s}}$ crossover and excluding or including lagged value of output. The main statistical significant variables are OPENECON (-), SHCOCPR (+), and MONPOL (-). These suggest that globalization (importing more relative to exports) has had dampening effect on agricultural growth. The same with MONPOL, which is associated with incidents of currency change, GDP rebasing, and drought. Giving a higher share of the cocoa f.o.b. price to farmers (SHCOCPR) has a boosting effect, perhaps by increasing farmers' investment in the agricultural sector. With respect to subsector-disaggregated output (7B.3b), those discussed above are also important in addition to several others, some differentiation by subsector. Those that have a common effect on both subsectors are MONPOL (-) and SHCOCAREA ( - for $Y_{c o c}$ and + for $Y_{\text {non }}$ ). Those that have a statistical significant effect on $Y_{\text {non }}$ only are OPENECON (-) and AGRFERT (+), whereas those that have a statistically significant effect on $Y_{c o c}$ only are SHCOCPR $(+)$, COCFERT $(+)$, and RAINCOV (-). Together with the above, these suggest the negative effect of MONPOL derives from both subsectors, whereas the negative effect of OPENECON derives mostly from the noncocoa subsector and the positive effect of SHCOCPR derives mostly from the cocoa subsector.

\footnotetext{
${ }^{5}$ Related to this, the subsector-disaggregated equations were estimated separately-i.e., the expenditure and output equations were jointly estimated for the noncocoa subsector, and then the expenditure and output equations were jointly estimated for the cocoa subsector. The results, which are not reported here, are consistent with those reported in this chapter.
} 
Table 7B.2a. Determinants of agricultural expenditure on cocoa and noncocoa subsectors in Ghana (with total agricultural output), 1961-2012

\begin{tabular}{|c|c|c|c|c|c|c|c|c|c|c|c|c|c|c|c|c|}
\hline & \multicolumn{8}{|c|}{ Allowing agSTK in one subsector to affect agEXP in own subsector only } & \multicolumn{8}{|c|}{ Allowing agSTK in one subsector to affect agEXP in the other subsector } \\
\hline & \multicolumn{4}{|c|}{ Without lag of output } & \multicolumn{4}{|c|}{ With lag of output } & \multicolumn{4}{|c|}{ Without lag of output } & \multicolumn{4}{|c|}{ With lag of output } \\
\hline & \multicolumn{2}{|c|}{ Noncocoa } & \multicolumn{2}{|c|}{ Cocoa } & \multicolumn{2}{|c|}{ Noncocoa } & \multicolumn{2}{|c|}{ Cocoa } & \multicolumn{2}{|c|}{ Noncocoa } & \multicolumn{2}{|c|}{ Cocoa } & \multicolumn{2}{|c|}{ Noncocoa } & \multicolumn{2}{|c|}{ Cocoa } \\
\hline & coeff & sig & coeff & sig & coeff & sig & coeff & sig & coeff & sig & coeff & sig & coeff & sig & coeff & sig \\
\hline agSTKnon & -4.972 & $* * *$ & & & -4.972 & $* * *$ & & & -7.668 & $* * *$ & 0.943 & & -7.615 & $* * *$ & 1.821 & \\
\hline agSTKcoc & & & -3.614 & $* *$ & & & -3.643 & $* *$ & 5.201 & $* * *$ & -3.639 & $* *$ & 5.260 & $* * *$ & -4.489 & $* * *$ \\
\hline GDPCAP & 1.029 & & -0.731 & & 1.046 & & -0.730 & & 1.686 & $* * *$ & -0.790 & & 1.613 & $* *$ & -1.192 & \\
\hline FOREX & -0.610 & $* * *$ & 0.065 & & -0.610 & $* * *$ & 0.064 & & -0.589 & $* * *$ & 0.102 & & -0.562 & $* * *$ & 0.066 & \\
\hline SHCOCPR & -0.004 & $* * *$ & -0.002 & $* *$ & -0.004 & $* * *$ & -0.002 & $* *$ & -0.005 & $* * *$ & -0.002 & $* *$ & -0.005 & $* * *$ & -0.001 & \\
\hline TOTEXP & 0.017 & $\star$ & -0.003 & & 0.017 & * & -0.003 & & 0.022 & $* *$ & -0.002 & & 0.022 & $* *$ & -0.007 & \\
\hline OPENECON & -0.429 & $* *$ & -0.124 & & -0.428 & $* *$ & -0.122 & & -0.603 & $* * *$ & -0.121 & & -0.598 & $* * *$ & -0.077 & \\
\hline ODAGDP & 0.039 & $* *$ & 0.011 & & 0.040 & $* *$ & 0.011 & & 0.033 & $* *$ & 0.010 & & 0.032 & $* *$ & 0.007 & \\
\hline GOVTYP & -0.091 & & -0.086 & & -0.093 & & -0.088 & & 0.009 & & -0.086 & & 0.013 & & -0.097 & \\
\hline MINFIN & -0.171 & $* *$ & -0.124 & & -0.170 & $* *$ & -0.124 & & -0.121 & * & -0.131 & & -0.116 & & -0.175 & $* *$ \\
\hline MINAG & 0.027 & & & & 0.028 & & & & -0.001 & & & & -0.012 & & & \\
\hline CEOCOB & & & -0.020 & & & & -0.020 & & & & -0.009 & & & & 0.047 & \\
\hline AGPOL & 0.088 & & & & 0.089 & & & & 0.065 & & & & 0.052 & & & \\
\hline COPOL & & & 0.032 & & & & 0.033 & & & & 0.022 & & & & 0.096 & \\
\hline AGPER & 0.013 & & 0.071 & & 0.011 & & 0.067 & & 0.204 & $* *$ & 0.073 & & 0.215 & $* *$ & 0.029 & \\
\hline POPGROW & -0.175 & & 0.287 & & -0.177 & & 0.285 & & -0.026 & & 0.326 & * & -0.017 & & 0.387 & * \\
\hline MONPOL & 0.159 & * & -0.068 & & 0.160 & * & -0.068 & & 0.193 & $* *$ & -0.074 & & 0.189 & $* *$ & -0.047 & \\
\hline RAINTOT & 0.101 & & -0.343 & * & 0.101 & & -0.340 & * & -0.059 & & -0.354 & * & -0.097 & & -0.274 & \\
\hline RAINCOV & -0.699 & $* * *$ & -0.051 & & -0.696 & $* * *$ & -0.053 & & -0.605 & $* * *$ & -0.053 & & -0.592 & $* * *$ & -0.283 & \\
\hline Intercept & 0.069 & & 0.267 & $* *$ & 0.069 & & 0.270 & $* *$ & -0.204 & $* *$ & 0.260 & $\star *$ & -0.203 & $* *$ & 0.280 & $* *$ \\
\hline F-statistic & 3.610 & $* * *$ & 2.590 & $* * *$ & 3.610 & $* * *$ & 2.590 & $* * *$ & 4.870 & $* * *$ & 2.380 & $* * *$ & 4.480 & $* * *$ & 2.350 & $* * *$ \\
\hline R-squared & 0.539 & & 0.441 & & 0.540 & & 0.441 & & 0.621 & & 0.445 & & 0.616 & & 0.446 & \\
\hline Rho & 0.000 & $(0.90)$ & 0.001 & $(0.86)$ & 0.000 & $(0.89)$ & 0.001 & $(0.86)$ & 0.000 & $(0.87)$ & 0.000 & $(0.93)$ & 0.000 & $(0.88)$ & 0.000 & $(0.93)$ \\
\hline System results & Rho $=0$ & $19(0.98$ & $\mathrm{BP}=3.4$ & $(0.32)$ & Rho $=0$ & $11(0.99$ & $3 \mathrm{P}=3.2$ & $(0.36)$ & Rho $=0$. & $15(0.98)$ & $\mathrm{BP}=8.07$ & $(0.04)^{\star *}$ & Rho $=0$. & $07(0.9$ & $\mathrm{BP}=7.6 \mathrm{~S}$ & $(0.05)^{\star *}$ \\
\hline
\end{tabular}

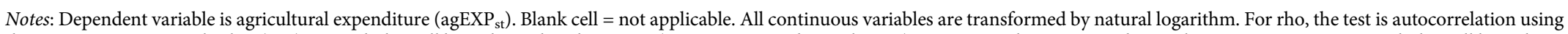

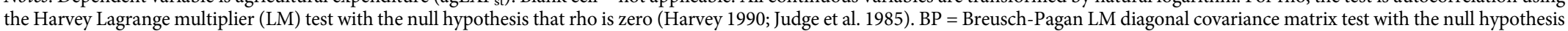

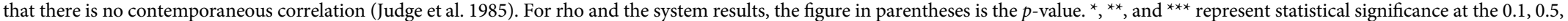
and 0.01 probability level, respectively.

Source: Author's representation based on model results. See Table 7B.1 for detail description of variables. 
Table 7B.2b. Effect of agricultural expenditure on total agricultural output in Ghana, 1961-2012

\begin{tabular}{|c|c|c|c|c|c|c|c|c|}
\hline & \multicolumn{4}{|c|}{$\begin{array}{l}\text { Allowing agSTK in one } \\
\text { subsector to affect agEXP } \\
\text { in own subsector only }\end{array}$} & \multicolumn{4}{|c|}{$\begin{array}{l}\text { Allowing agSTK in one } \\
\text { subsector to affect agEXP } \\
\text { in the other subsector }\end{array}$} \\
\hline & \multicolumn{2}{|c|}{$\begin{array}{l}\text { Without lag of } \\
\text { output }\end{array}$} & \multicolumn{2}{|c|}{$\begin{array}{l}\text { With lag of } \\
\text { output }\end{array}$} & \multicolumn{2}{|c|}{$\begin{array}{l}\text { Without lag of } \\
\text { output }\end{array}$} & \multicolumn{2}{|c|}{$\begin{array}{l}\text { With lag of } \\
\text { output }\end{array}$} \\
\hline & coeff & sig & coeff & sig & coeff & sig & coeff & sig \\
\hline $\operatorname{agEXP}_{\text {non }}$ & 0.103 & $* *$ & 0.101 & $* *$ & 0.112 & $* * *$ & 0.130 & $* * *$ \\
\hline $\operatorname{agSTK}_{\text {non }}$ & 0.860 & * & 0.882 & * & 1.011 & $* *$ & 1.214 & $* *$ \\
\hline $\operatorname{agEXP}_{c o c}$ & 0.058 & & 0.054 & & 0.076 & & 0.002 & \\
\hline $\operatorname{agSTK}_{\mathrm{coc}}$ & -0.182 & & -0.195 & & -0.363 & & -0.729 & \\
\hline TOTEXP & 0.000 & & 0.000 & & 0.001 & & 0.001 & \\
\hline OPENECON & -0.085 & * & -0.083 & * & -0.081 & * & -0.091 & * \\
\hline SHCOCPR & 0.001 & $* *$ & 0.001 & $* *$ & 0.001 & $* *$ & 0.001 & * \\
\hline COCFERT & 0.032 & & 0.032 & & 0.025 & & 0.018 & \\
\hline AGRFERT & 0.035 & & 0.034 & & 0.050 & & 0.073 & * \\
\hline GOLDCOC & -0.057 & & -0.060 & & -0.046 & & -0.026 & \\
\hline GOLDAGR & -0.087 & & -0.084 & & -0.094 & & -0.089 & \\
\hline SHCOCAREA & 0.748 & & 0.825 & & 0.402 & & 0.746 & \\
\hline POPGROW & -0.010 & & -0.010 & & -0.019 & & 0.002 & \\
\hline MONPOL & -0.088 & $* * *$ & -0.090 & $* * *$ & -0.092 & $* * *$ & -0.100 & $* * *$ \\
\hline RAINTOT & -0.061 & & -0.059 & & -0.078 & & -0.079 & \\
\hline RAINCOV & 0.020 & & 0.020 & & 0.011 & & 0.001 & \\
\hline $\begin{array}{l}\text { Lag of output } \\
\left(\mathrm{Y}_{\mathrm{t}-1}\right)\end{array}$ & & & -0.035 & & & & -0.037 & \\
\hline Intercept & 0.038 & * & 0.040 & * & 0.044 & * & 0.062 & $* * *$ \\
\hline F-statistic & 4.360 & $* * *$ & 4.140 & $* * *$ & 4.530 & $* * *$ & 4.600 & $* * *$ \\
\hline R-squared & 0.571 & & 0.574 & & 0.555 & & 0.494 & \\
\hline $\begin{array}{l}\text { Total effect } \\
\left(\text { agEXP }_{\text {non }}+\right. \\
\left.\text { agSTK }_{\text {non }}\right)\end{array}$ & 0.452 & & 0.479 & & 0.336 & & 0.356 & \\
\hline $\begin{array}{l}\text { Total effect } \\
\left(\text { agEXP }_{\text {coc }}+\right. \\
\left.\text { agSTK }_{\text {coc }}\right)\end{array}$ & -0.334 & & -0.337 & & 0.018 & & -0.051 & \\
\hline Rho & 0.003 & $(0.70)$ & 0.001 & $(0.80)$ & 0.002 & $(0.73)$ & 0.001 & $(0.84)$ \\
\hline System results & \multicolumn{2}{|c|}{$\begin{array}{l}\text { Rho }=0.19 \\
(0.98) ; \mathrm{BP}= \\
3.47(0.32)\end{array}$} & \multicolumn{2}{|c|}{$\begin{array}{l}\text { Rho }=0.11 \\
(0.99) ; \mathrm{BP}= \\
3.21(0.36)\end{array}$} & \multicolumn{2}{|c|}{$\begin{array}{l}\text { Rho }=0.15 \\
(0.98) ; \mathrm{BP}= \\
8.07(0.04)^{\star *}\end{array}$} & \multicolumn{2}{|c|}{$\begin{array}{l}\text { Rho }=0.07 \\
(0.99) ; \mathrm{BP}= \\
7.69(0.05)^{\star *}\end{array}$} \\
\hline
\end{tabular}

Notes: Dependent variable is agricultural output $\left(\mathrm{Y}_{\mathrm{t}}\right)$. Blank cell $=$ not applicable. All continuous variables are transformed by natural logarithm. Total effect is obtained by summing elasticities with respect to agEXP st $_{\text {and agSTK }}$. and agSTK st $_{\text {indirectly via agEXP }}$ st. For rho, the test is autocorrelation using the Harvey Lagrange multiplier (LM) test with the null hypothesis that rho is zero (Harvey 1990; Judge et al. 1985). BP = Breusch-Pagan LM diagonal covariance matrix test with the null hypothesis that there is no contemporaneous correlation (Judge et al. 1985). For rho and the system results, the figure in parentheses is the $p$-value. ${ }^{*}, * *$, and ${ }^{* *}$ represent statistical significance at the $0.1,0.5$, and 0.01 probability level, respectively.

Source: Author's representation based on model results. See Table 7B.1 for detail description of variables. 
Table 7B.3a. Determinants of agricultural expenditure on cocoa and noncocoa subsectors in Ghana (with subsector agricultural output), 1961-2012

\begin{tabular}{|c|c|c|c|c|c|c|c|c|c|c|c|c|c|c|c|c|}
\hline & \multicolumn{8}{|c|}{ Allowing agSTK in one subsector to affect agEXP in own subsector only } & \multicolumn{8}{|c|}{ Allowing agSTK in one subsector to affect agEXP in the other subsector } \\
\hline & \multicolumn{4}{|c|}{ Without lag of output } & \multicolumn{4}{|c|}{ With lag of output } & \multicolumn{4}{|c|}{ Without lag of output } & \multicolumn{4}{|c|}{ With lag of output } \\
\hline & \multicolumn{2}{|c|}{ Noncocoa } & \multicolumn{2}{|c|}{ Cocoa } & \multicolumn{2}{|c|}{ Noncocoa } & \multicolumn{2}{|c|}{ Cocoa } & \multicolumn{2}{|c|}{ Noncocoa } & \multicolumn{2}{|c|}{ Cocoa } & \multicolumn{2}{|c|}{ Noncocoa } & \multicolumn{2}{|c|}{ Cocoa } \\
\hline & coeff & sig & coeff & sig & coeff & sig & coeff & sig & coeff & sig & coeff & sig & coeff & sig & coeff & sig \\
\hline $\operatorname{agSTK}_{\text {non }}$ & -4.782 & $* * *$ & & & -4.842 & $* * *$ & & & -7.022 & $* * *$ & 1.282 & & -7.201 & $* * *$ & 1.295 & \\
\hline agSTK $_{\mathrm{coc}}$ & & & -3.641 & $* *$ & & & -3.454 & ** & 4.419 & $* * *$ & -4.052 & $* *$ & 4.601 & $* * *$ & -3.879 & ** \\
\hline GDPCAP & 1.125 & * & -0.753 & & 1.165 & * & -0.557 & & 1.739 & $* * *$ & -0.873 & & 1.765 & $* * *$ & -0.703 & \\
\hline FOREX & -0.582 & $* * *$ & 0.077 & & -0.606 & $* * *$ & 0.135 & & -0.580 & $* * *$ & 0.104 & & -0.591 & $* * *$ & 0.138 & \\
\hline SHCOCPR & -0.004 & $* * *$ & -0.003 & $* *$ & -0.004 & $* * *$ & -0.002 & $* *$ & -0.005 & $* * *$ & -0.003 & $* *$ & -0.005 & $* * *$ & -0.002 & $* *$ \\
\hline TOTEXP & 0.011 & & -0.004 & & 0.012 & & -0.004 & & 0.016 & $*$ & -0.003 & & 0.017 & $* *$ & -0.003 & \\
\hline OPENECON & -0.359 & $* *$ & -0.110 & & -0.374 & ** & -0.137 & & -0.528 & $* * *$ & -0.097 & & -0.546 & $* * *$ & -0.118 & \\
\hline ODAGDP & 0.048 & $* * *$ & 0.012 & & 0.048 & $* * *$ & 0.012 & & 0.042 & $* * *$ & 0.012 & & 0.041 & $* *$ & 0.012 & \\
\hline GOVTYP & -0.154 & $* *$ & -0.098 & & -0.147 & $* *$ & -0.098 & & -0.063 & & -0.110 & & -0.050 & & -0.106 & \\
\hline MINFIN & -0.168 & $* *$ & -0.110 & & -0.172 & $* *$ & -0.120 & & -0.133 & * & -0.121 & & -0.133 & * & -0.125 & \\
\hline MINAG & 0.095 & & & & 0.085 & & & & 0.056 & & & & 0.045 & & & \\
\hline CEOCOB & & & -0.017 & & & & -0.009 & & & & -0.002 & & & & 0.000 & \\
\hline AGPOL & 0.167 & * & & & 0.159 & & & & 0.145 & & & & 0.133 & & & \\
\hline COPOL & & & 0.044 & & & & 0.059 & & & & 0.034 & & & & 0.042 & \\
\hline AGPER & -0.081 & & 0.037 & & -0.066 & & 0.046 & & 0.106 & & 0.021 & & 0.130 & & 0.036 & \\
\hline POPGROW & -0.252 & & 0.277 & & -0.240 & & 0.292 & & -0.105 & & 0.312 & & -0.091 & & 0.327 & * \\
\hline MONPOL & 0.198 & $* *$ & -0.061 & & 0.194 & $* *$ & -0.050 & & 0.225 & $* * *$ & -0.068 & & 0.220 & $* * *$ & -0.061 & \\
\hline RAINTOT & 0.187 & & -0.320 & * & 0.173 & & -0.293 & & 0.048 & & -0.318 & * & 0.031 & & -0.306 & \\
\hline RAINCOV & -0.767 & $* * *$ & -0.061 & & -0.763 & $* * *$ & -0.066 & & -0.691 & $* * *$ & -0.078 & & 0.678 & $* * *$ & -0.075 & \\
\hline Intercept & 0.060 & & 0.273 & $* * *$ & 0.061 & & 0.261 & $* *$ & -0.171 & $*$ & 0.287 & $* *$ & -0.179 & $* *$ & 0.274 & $* *$ \\
\hline F-statistic & 3.920 & $* * *$ & 2.620 & $* * *$ & 3.910 & $* * *$ & 2.590 & $* * *$ & 4.990 & $* * *$ & 2.450 & $* * *$ & 5.020 & $* * *$ & 2.420 & $* * *$ \\
\hline R-squared & 0.530 & & 0.438 & & 0.536 & & 0.433 & & 0.625 & & 0.443 & & 0.628 & & 0.442 & \\
\hline Rho & 0.002 & $(0.75)$ & 0.000 & $(0.94)$ & 0.001 & $(0.79)$ & 0.000 & $(0.97)$ & 0.000 & $(1.00)$ & 0.000 & $(0.92)$ & 0.000 & $(1.00)$ & 0.000 & $(0.94)$ \\
\hline System results & Rho $=1$ & $2(0.89)$ & $=13.8 \mathrm{C}$ & $(0.03)^{* *}$ & Rho $=0$. & $19(0.99)$ & $=12.5$ & $(0.05)^{* *}$ & Rho $=1$ & $10(0.89$ & $\mathrm{P}=10.3$ & $7(0.11)$ & Rho $=0$ & $21(0.5$ & $3 \mathrm{P}=8.6$ & $9(0.19)$ \\
\hline
\end{tabular}

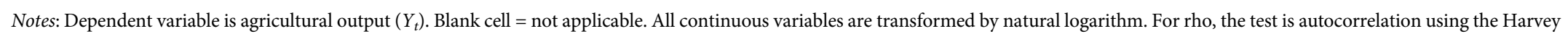

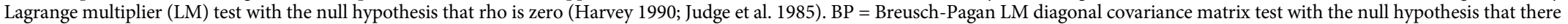

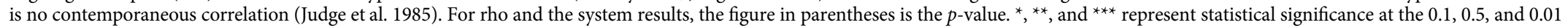
probability level, respectively.

Source: Author's representation based on model results. See Table 5B.1 for detail description of variables. 
Table 7B.3b. Effect of subsector agricultural expenditure on subsector agricultural output in Ghana, 1961-2012

\begin{tabular}{|c|c|c|c|c|c|c|c|c|c|c|c|c|c|c|c|c|}
\hline & \multicolumn{8}{|c|}{ Allowing agSTK and agEXP own subsector output only } & \multicolumn{8}{|c|}{ Allowing agSTK in one subsector to affect output in the other subsector } \\
\hline & \multicolumn{4}{|c|}{ Without lag of output } & \multicolumn{4}{|c|}{ With lag of output } & \multicolumn{4}{|c|}{ Without lag of output } & \multicolumn{4}{|c|}{ With lag of output } \\
\hline & \multicolumn{2}{|c|}{ Noncocoa } & \multicolumn{2}{|c|}{ Cocoa } & \multicolumn{2}{|c|}{ Noncocoa } & \multicolumn{2}{|c|}{ Cocoa } & \multicolumn{2}{|c|}{ Noncocoa } & \multicolumn{2}{|c|}{ Cocoa } & \multicolumn{2}{|c|}{ Noncocoa } & \multicolumn{2}{|c|}{ Cocoa } \\
\hline & coeff & sig & coeff & sig & coeff & sig & coeff & sig & coeff & sig & coeff & sig & coeff & sig & coeff & sig \\
\hline $\operatorname{agEXP}_{\text {non }}$ & -0.010 & & & & 0.016 & & & & 0.013 & & & & 0.038 & & & \\
\hline agSTK $_{\text {non }}$ & 0.748 & * & & & 0.781 & * & & & 1.086 & $* *$ & -2.712 & & 1.103 & $* *$ & -2.597 & \\
\hline $\operatorname{agEXP}_{\mathrm{coc}}$ & & & 0.487 & & & & 0.697 & $* *$ & & & 0.498 & * & & & 0.631 & $* *$ \\
\hline $\operatorname{agSTK}_{\mathrm{coc}}$ & & & -0.837 & & & & -0.211 & & -0.058 & & 0.272 & & -0.149 & & 0.639 & \\
\hline TOTEXP & 0.001 & & 0.014 & & 0.001 & & 0.012 & & 0.001 & & 0.011 & & 0.001 & & 0.009 & \\
\hline OPENECON & -0.182 & $* * *$ & 0.212 & & -0.185 & $* * *$ & 0.287 & & -0.177 & $* * *$ & 0.225 & & -0.181 & $* * *$ & 0.276 & \\
\hline SHCOCPR & & & 0.002 & * & & & 0.003 & $* *$ & & & 0.002 & * & & & 0.003 & ** \\
\hline COCFERT & & & 0.156 & * & & & 0.153 & * & & & 0.183 & $* *$ & & & 0.178 & * \\
\hline AGRFERT & 0.081 & $* * *$ & & & 0.083 & $* * *$ & & & 0.081 & $* * *$ & & & 0.084 & $* * *$ & & \\
\hline GOLDCOC & & & 0.107 & & & & 0.044 & & & & 0.181 & & & & 0.138 & \\
\hline GOLDAGR & -0.193 & & & & -0.189 & & & & -0.175 & & & & -0.168 & & & \\
\hline SHCOCAREA & 2.684 & $* *$ & -10.525 & $* *$ & 2.577 & $* *$ & -12.528 & $* *$ & 2.646 & $* *$ & -11.121 & $* *$ & 2.505 & $* *$ & -12.543 & $* *$ \\
\hline POPGROW & -0.004 & & -0.300 & & 0.005 & & -0.342 & & 0.013 & & -0.369 & & 0.019 & & -0.390 & \\
\hline MONPOL & -0.066 & $* * *$ & -0.250 & $* *$ & -0.062 & $* *$ & -0.229 & $* *$ & -0.067 & $* * *$ & -0.228 & $* *$ & -0.064 & $* *$ & -0.213 & * \\
\hline RAINTOT & -0.088 & & 0.084 & & -0.086 & & 0.042 & & -0.080 & & 0.065 & & -0.083 & & 0.036 & \\
\hline RAINCOV & -0.055 & & 1.056 & $* * *$ & -0.063 & & 1.117 & $* * *$ & -0.053 & & 1.030 & $* * *$ & -0.064 & & 1.085 & $* * *$ \\
\hline Lag of output $\left(\mathrm{Y}_{\text {non }}\right)$ & & & & & 0.072 & & & & & & & & 0.082 & & & \\
\hline Lag of output $\left(\mathrm{Y}_{\mathrm{coc}}\right)$ & & & & & & & 0.134 & & & & & & & & 0.107 & \\
\hline Intercept & 0.036 & $* * *$ & 0.070 & & 0.033 & $* * *$ & 0.032 & & 0.034 & * & 0.047 & & 0.035 & * & 0.022 & \\
\hline F-statistic & 4.460 & $* * *$ & 3.130 & $* * *$ & 4.250 & $* * *$ & 3.130 & $* * *$ & 4.190 & $* * *$ & 3.020 & $* * *$ & 4.050 & $* * *$ & 2.950 & $* * *$ \\
\hline R-squared & 0.476 & & 0.440 & & 0.499 & & 0.441 & & 0.493 & & 0.456 & & 0.506 & & 0.465 & \\
\hline Total effect $\left(\operatorname{agEXP}_{\text {non }}+\operatorname{agSTK}_{\text {non }}\right)$ & 0.787 & * & & & 0.718 & & & & 1.007 & $* *$ & -2.074 & & 0.865 & * & -1.781 & \\
\hline 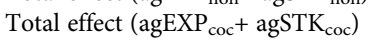 & & & -2.123 & & & & -1.922 & & -1.248 & & -0.001 & & -1.177 & & 0.028 & \\
\hline Rho & 0.010 & $(0.48)$ & 0.010 & $(0.47)$ & 0.002 & $(0.77)$ & 0.001 & $(0.87)$ & 0.008 & $(0.52)$ & 0.014 & $(0.41)$ & 0.006 & $(0.86)$ & 0.003 & $(0.68)$ \\
\hline System results & Rho $=1$ & $12(0.89)$ & $3 P=13.86$ & $(0.03)^{\star *}$ & Rho $=0$. & $9(0.99)$ & $3 \mathrm{P}=12.57$ & $(0.05)^{* *}$ & Rho $=1$. & $(0.89)$ & $=10.37($ & 11) & Rho $=$ & $1(0.99)$ & $=8.69(0$. & \\
\hline
\end{tabular}

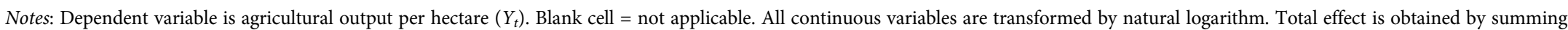

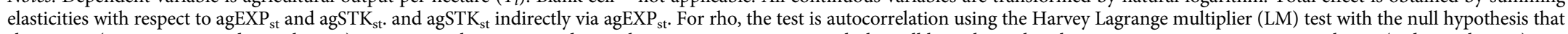

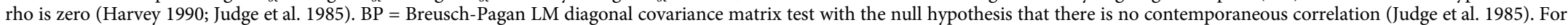
rho and the system results, the figure in parentheses is the $p$-value. ${ }^{*},{ }^{* *}$, and ${ }^{* * *}$ represent statistical significance at the $0.1,0.5$, and 0.01 probability level, respectively.

Source: Author's representation based on model results. See Table 5B.1 for detailed description of variables. 


\section{References}

Andah, E. K. 1980. “Action Programme for Agricultural production, 1980-81.” Accra: Ministry of Food and Agriculture.

Aschauer, D. A. 1989. “Is Public Expenditure Productive?” Journal of Monetary Economics 23: 177-200.

Austin, D., and R. Luckham. 1975. Politicians and Soldiers in Ghana 1966-1972. London: Cass University Paperbacks.

Barro, R. 1990. "Government Spending in a Simple Model of Endogenous Growth.” Journal of Political Economy 98(5): 103-25.

Benin, Samuel. 2014. "Identifying Agricultural Expenditures within the Public Financial Accounts and Coding System in Ghana: Is the 10 Percent Government Agriculture Expenditure Overestimated?” IFPRI Discussion Paper No. 1365. Washington, DC: International Food Policy Research Institute.

Benin, Samuel. 2015. “Impact of Ghana’s Agricultural Mechanization Services Center Program.” Agricultural Economics 46(1): 103-17.

Benin, Samuel. 2016. "Returns to Agricultural Public Spending in Ghana: Cocoa versus Noncocoa Subsector.” IFPRI Discussion Paper No. 01503. Washington DC: International Food Policy Research Institute.

Benin, S., M. Johnson, E. Abokyi et al. 2013. "Revisiting Agricultural Input and Farm Support Subsidies in Africa: The Case of Ghana's Mechanization, Fertilizer, Block Farms, and Marketing Programs.” IFPRI Discussion Paper No. 1300. Washington, DC: International Food Policy Research Institute.

Benin, S., T. Mogues, G. Cudjoe, and J. Randriamamonjy. 2012. "Public Expenditures and Agricultural Productivity Growth in Ghana," in T. Mogues and S. Benin (eds), Public Expenditures for Agricultural and Rural Development in Africa. London: Routledge; New York: Taylor and Francis Group.

Benin, S., and B. Yu. 2013. "Complying with the Maputo Declaration Target: Trends in Public Agricultural Expenditures and Implications for Pursuit of Optimal Allocation of Public Agricultural Spending. ReSAKSS Annual Trends and Outlook Report 2012." Washington, DC: International Food Policy Research Institute.

Breusch, T. S., and A. R. Pagan. 1980. "The Lagrange Multiplier Test and its Applications to Model Specification in Econometrics." Review of Economic Studies 47: 239-53.

CAGD (Controller and Accountant General's Department). 2011. "Report of the Auditor General on the Public Accounts of the Government of Ghana for the Year Ended 31 December 2010." Accra, Ghana.

CAGD (Controller and Accountant General's Department). 2013. "Report of the Auditor General on the Public Accounts of the Government of Ghana for the Year Ended 31 December 2012." Accra, Ghana. 
CAGD (Controller and Accountant General's Department). 2014. "Report of the Auditor General on the Public Accounts of the Government of Ghana for the Year Ended 31 December 2013.” Accra, Ghana.

Dappah, S. K. 1995. "Empirical Analysis of the Likely Future Evolution of Agriculture in Ghana and How It Will Affect the Prospects for Longer-term Growth of Agriculture, the Food System and the Broader Economy." Paper presented at the workshop on Agricultural Transformation in Africa, Abidjan, Cote d'Ivoire, September 26-29.

Dickey, D. A., and W. A. Fuller. 1979. "Distribution of the Estimators for Autoregressive Time Series with a Unit Root." Journal of the American Statistical Association 74: 427-31.

Fan, S. (ed.). 2008. Public Expenditures, Growth, and Poverty: Lessons from Developing Countries. Baltimore, MD: Johns Hopkins University Press.

Fan, Shenggen, Peter Hazell, and Sukhadeo Thorat. 2000. "Government Spending, Growth and Poverty in India." American Journal of Agricultural Economics 82(4): 1038-51.

FAO (Food and Agriculture Organization of the United Nations). 2016. "FAOSTAT: Commodities by Country.” Available at: http://faostat.fao.org/site/339/ default.aspx.

Garrett, G. 2001. "Globalization and Government Spending around the World." Studies in Comparative International Development 35(4): 3-29.

GCB (The Ghana Cocoa Board). 2013. “44th Annual Report \& Financial Statements for the Year Ended 30th September, 2013.” Accra: Ghana Cocoa Board.

Greene, W. H. 1993. Econometric Analysis. New York: Macmillan.

HarvestChoice. 2015. "Long-Term Climate Trends for Sub-Saharan Africa." Database. Available at: http://harvestchoice.org/tools/long-term-climate-trendsand-variations-sub-saharan-africa.

Harvey, A. C. 1990. The Econometric Analysis of Time Series, 2nd ed. Cambridge, MA: MIT Press.

Hsiao, C. 1986. Analysis of Panel Data. Cambridge: Cambridge University Press.

IFPRI (International Food Policy Research Institute). 2015. "Public Expenditure Database: Statistics on Public Expenditure for Economic Development (SPEED)." Available at: http://www.ifpri.org/book-39/ourwork/programs/priorities-publicinvestment/speed-database.

IMF. 1998. Ghana: Statistical Annex. IMF Country Report No. 98/2. Washington, DC: IMF.

IMF. 2000. Ghana: Statistical Annex. IMF Staff Country Report No. 1. Washington, DC: IMF.

IMF. 2005. Ghana: Statistical Appendix. IMF Country Report No. 05/286. Washington, DC: IMF. 
Judge, G., W. E. Griffiths, R. C. Hill et al. 1985. The Theory and Practice of Econometrics, 2nd ed. New York: John Wiley \& Sons.

Kohli, U. 1982. "A Gross National Function Product and the Derived Demand for Imports and Supply of Exports." Canadian Journal of Economics 18: 369-86.

Kolavalli, S., M. Vigneri, H. Maamah, and J. Poku. 2012. “The Partially Liberalized Cocoa Sector in Ghana: Producer Price Determination, Quality Control, and Service Provision.” IFPRI Discussion Paper No. 1213. Washington, DC: International Food Policy Research Institute.

Knoema. 2016. “Average Depreciation Rate of the Capital Stock.” Available at: https://knoema.com/PWT2015/penn-world-table-9-0?tsId=1015390.

MoFA. 1999. Agricultural Sector Expenditure Review, 1995-1997. Accra: Ministry of Food and Agriculture.

MoFA. 2013. “Basic Agricultural Public Expenditure Diagnostic Review.” Report under Strengthening National Comprehensive Agricultural Public Expenditure in Sub-Saharan Africa. Washington, DC: World Bank.

Mogues, T., and S. Benin. 2012. "Do External Grants to District Governments Leverage Own-revenue Generation? A Look at Local Public Finance Dynamics in Ghana." World Development 40(5): 1054-67.

Peacock, A. T., and J. Wiseman. 1961. "The Growth of Public Expenditure in the United Kingdom.” NBER General Series 72. Princeton, NJ: Princeton University Press.

Phillips, P. C. B., and P. Perron. 1988. “Testing for a Unit Root in Time Series Regression.” Biometrika 75: 335-46.

Quartey-Papafio, H. K. 1977. "Report of the Operation Feed Yourself and Operation Feed Your Industries Review Committee.” Accra: Council for Scientific and Industrial Research.

Rodrik, D. 1998. "Why Do More Open Economies Have Bigger Governments?" Journal of Political Economy 106(5): 997-1032.

Sadoulet, E., and A. de Janvry. 1995. Quantitative Development Policy Analysis. Baltimore, MD: Johns Hopkins University Press.

Schultz, T. W. 1982. Investing in People: The Economics of Population Quality. Berkeley, CA: University of California Press.

Stryker, J. D. 1990. Trade, Exchange Rate, and Agricultural Pricing Policies in Ghana. World Bank Comparative Studies 8399. Washington, DC: World Bank.

Thirtle, C., J. Piesse, and L. Lin. 2003. “The Impact of Research-Led Agricultural Productivity Growth on Poverty Reduction in Africa, Asia and Latin America.” World Development 31(12): 1959-75.

Wagner, A. 1883. Finanzwissenschaft, 3rd ed. Leipzig: C. F. Winter. Partially reprinted in R. A. Musgrave and A. T. Peacock (eds), Classics in the Theory of Public Finance. London: Macmillan. 
Wiemers, A. 2015. “'Time of Agric': Rethinking the 'Failure' of Agricultural Programs in 1970s Ghana.” World Development 66: 104-17.

World Bank. 2015. World Development Indicators. Washington, DC.

World Bank. 2016a. World Development Indicators. Washington, DC.

World Bank. 2016b. “Commodity Markets: Annual Prices.” Available at: http:// www.worldbank.org/en/research/commodity-markets.

Zellner, A., and H. Theil. 1962. "Three Stage Least Squares: Simultaneous Estimate of Simultaneous Equations.” Econometrica 29: 54-78. 